\title{
Climate Change Amplification of Natural Drought Variability: The Historic Mid-Twentieth-Century North American Drought in a Warmer World
}

\author{
Benjamin I. CoOK, ${ }^{\mathrm{a}, \mathrm{b}}$ Richard SeAger, ${ }^{\mathrm{b}}$ A. PARK Williams, ${ }^{\mathrm{c}}$ Michael J. Puma, ${ }^{\mathrm{d}}$ \\ SONAli MCDERMid, ${ }^{\mathrm{e}}$ MAXWEll KELlEy, ${ }^{\mathrm{a}}$ AND LARISSA NAZARENKO ${ }^{\mathrm{a}}$ \\ ${ }^{\text {a }}$ NASA Goddard Institute for Space Studies, New York, New York \\ ${ }^{\mathrm{b}}$ Division of Ocean and Climate Physics, Lamont-Doherty Earth Observatory, Palisades, New York \\ ${ }^{\mathrm{c}}$ Tree Ring Lab, Lamont-Doherty Earth Observatory, Palisades, New York \\ ${ }^{\mathrm{d}}$ Center for Climate Systems Research, Columbia University, New York, New York \\ ${ }^{\mathrm{e}}$ Department of Environmental Studies, New York University, New York, New York
}

(Manuscript received 5 December 2018, in final form 15 May 2019)

\begin{abstract}
In the mid-twentieth century (1948-57), North America experienced a severe drought forced by cold tropical Pacific sea surface temperatures (SSTs). If these SSTs recurred, it would likely cause another drought, but in a world substantially warmer than the one in which the original event took place. We use a 20-member ensemble of the GISS climate model to investigate the drought impacts of a repetition of the mid-twentiethcentury SST anomalies in a significantly warmer world. Using observed SSTs and mid-twentieth-century forcings (Hist-DRGHT), the ensemble reproduces the observed precipitation deficits during the cold season (October-March) across the Southwest, southern plains, and Mexico and during the warm season (AprilSeptember) in the southern plains and the Southeast. Under analogous SST forcing and enhanced warming (Fut-DRGHT, $\approx 3 \mathrm{~K}$ above preindustrial), cold season precipitation deficits are ameliorated in the Southwest and southern plains and intensified in the Southeast, whereas during the warm season precipitation deficits are enhanced across North America. This occurs primarily from greenhouse gas-forced trends in mean precipitation, rather than changes in SST teleconnections. Cold season runoff deficits in Fut-DRGHT are significantly amplified over the Southeast, but otherwise similar to Hist-DRGHT over the Southwest and southern plains. In the warm season, however, runoff and soil moisture deficits during Fut-DRGHT are significantly amplified across the southern United States, a consequence of enhanced precipitation deficits and increased evaporative losses due to warming. Our study highlights how internal variability and greenhouse gas-forced trends in hydroclimate are likely to interact over North America, including how changes in both precipitation and evaporative demand will affect future drought.
\end{abstract}

\section{Introduction}

In the 1950s, a severe and prolonged drought affected much of North America, including northern Mexico, seven western states (California, Nevada, Arizona, Utah, Colorado, New Mexico, Texas), much of the southeastern United States, and two major river basins (the Colorado and Rio Grande) (Andreadis et al. 2005; Heim 2017; Nace and Pluhowski 1965; Quiring and Goodrich 2008). At its peak in 1956, this drought covered $51 \%$ of the contiguous United States (Heim 1988), with precipitation deficits $\approx 75 \%$ of normal over onethird of the United States and below 50\% for much of

Corresponding author: Benjamin I. Cook, benjamin.i.cook@ nasa.gov the U.S. Southwest (Palmer and Seamon 1957). This event would ultimately rank as one of the most extreme droughts in the historical record (Lowry 1959; Moore 2005; Nielsen-Gammon 2011; Quiring and Goodrich 2008; Williams et al. 2017; Winters 2013), becoming the "drought of record" for many areas of the southern United States (McGregor 2015; Moore 2005; Thomas 1963) and exceeding the severity of some of the worst events in tree-ring-based drought reconstructions of the last millennium (Fye et al. 2003; Stahle and Cleaveland 1988; Woodhouse and Overpeck 1998).

Moisture deficits associated with the 1950s drought had significant impacts on water resources, agriculture, and ecosystems. At Lee's Ferry on the Colorado River, flow from the upper basin during 1953-56 averaged only 6.6 million acre-feet $\mathrm{yr}^{-1}$, a marked decline from the 
historical-average flows of 15.3 million acre-feet $\mathrm{yr}^{-1}$ from 1897 to 1929 (Thomas 1963). From 1943 to 1956, upstream divisions of Rio Grande flow (San Luis Valley in Colorado, Middle Valley in New Mexico) failed to deliver water in accordance with the provisions of the Rio Grande Compact of 1938 (Thomas 1963). By 1951, carryover storage in the Elephant Butte reservoir on the Rio Grande was no longer sufficient to meet demand, leading to a failure of water deliveries downstream and spurring development of groundwater resources in New Mexico, Texas, and Mexico to compensate (Thomas 1963). Across the Southwest and southern plains, dairy farmers sold off or butchered their herds and breeding stock, while in Kansas two-thirds of the 115000 farmers in that state were forced to find off-farm jobs (Hughes 1976). In Texas alone, this drought destroyed onequarter (estimated at $\$ 2.7$ billion) of the state's agricultural potential (Hughes 1976), resulting in 236 of 254 counties becoming declared disaster areas and over 100000 people receiving federal food aid (Tedesco 2015). Indeed, the impacts of the drought in Texas were so severe that they prompted the creation of the Texas Water Development board in 1957, which began a series of reservoir construction projects across the state (Tedesco 2015). The drought also caused major episodes of ecological disruption, including vegetation mortality, wind erosion, and turnover of plant communities (e.g., Chepil et al. 1963; Herbel et al. 1972; Nace and Pluhowski 1965; Neilson 1986; Swetnam and Betancourt 1998; Weiss et al. 2012). One of the most notable examples occurred in New Mexico, where droughtinduced mortality of ponderosa pine forests allowed for the expansion of piñon-juniper woodlands, an ecosystem state shift that has persisted for decades (Allen and Breshears 1998).

The precipitation deficits that caused the 1950s drought are attributed primarily to a series of strong La Niña events and persistent cold sea surface temperature (SST) anomalies in the eastern tropical Pacific (Hoerling et al. 2009; Seager et al. 2005), a pattern typically associated with drought across the southern United States (Schubert et al. 2009, 2016; Seager and Hoerling 2014). This drought also occurred within a multidecadal period of relative dryness over North America related to warm conditions in the tropical Atlantic (a positive phase of the Atlantic multidecadal oscillation; McCabe et al. 2004; Nigam et al. 2011). Such SST-forced droughts have occurred naturally and with some regularity in past centuries (Herweijer et al. 2007; Seager et al. 2005) and more recent decades (Delworth et al. 2015; Seager 2007). As these ocean dynamics are expected to remain an important component of natural variability in the future (Fuentes-Franco et al. 2016), there is a reasonable likelihood that the ocean conditions that caused the 1950s drought could happen again, with the added complication that any associated SST-forced drought would occur in a much warmer world. Since climate change is expected to amplify drying and drought risk in much of North America (Cook et al. 2015a; Seager et al. 2014), a future drought analogous to the event that occurred in the 1950 s could potentially be much more severe.

In this study, we investigate how global warming would impact the 1950s drought event, using a new 20member SST-forced ensemble of the Goddard Institute for Space Studies (GISS) climate model (ModelE). From 1870 to 2014, the ensemble is forced using the standard historical forcings from phase 6 of the Coupled Model Intercomparison Project (CMIP6) and observed historically varying SSTs. From 2015 to 2100, we then use a high-forcing greenhouse gas (GHG) scenario and a modified SST record where twenty-first-century GHGforced SST trends are superimposed on the observed SST record. With this approach, we replicated the SST conditions that caused the historical drought (1948-57; Hist-DRGHT) during the middle of the twenty-first century, but with significantly higher GHG concentrations and warmer global temperatures (2048-57; FutDRGHT). We compared the model response between these Hist-DRGHT and Fut-DRGHT periods to investigate the following questions: 1) How does warming affect the magnitude of SST-forced drought anomalies (precipitation, runoff, soil moisture) over the southern United States? 2) To what extent are the changes in precipitation due to shifts in the nature of the SST teleconnections versus a direct response to enhanced GHG forcing? 3) What processes aside from precipitation are important for amplifying or ameliorating SST-forced surface moisture deficits (runoff, soil moisture) under enhanced GHG warming?

\section{Methods and data}

\section{a. The GISS-SST ensemble}

The GISS-SST ensemble is a 20 -member ensemble of the GISS climate model, ModelE (Schmidt et al. 2014), run from 1870 to 2100 . While running at the same nominal spatial resolution $\left(2^{\circ} \times 2.5^{\circ}\right)$ as the most recently published version of the model [used for phase 5 of the Coupled Model Intercomparison Project (CMIP5)], this version of ModelE (ModelE2.1) includes substantial improvements to various processes. Initial conditions for the atmosphere and land surface for each ensemble member were taken from randomly selected years in a 500-yr control simulation using fixed 
1850 forcings (e.g., GHG concentrations) and prescribed climatological (1876-85) SSTs and sea ice concentrations (fractional cover) from the historical HadISST dataset (Rayner et al. 2003). From 1870 to 2014, each ensemble member was forced with the historical forcings from the CMIP6 protocols (Eyring et al. 2016) and historically varying SSTs and sea ice concentrations from HadISST.

From 2015 to 2100 , the GISS-SST ensemble used forcings from the high-warming representative concentration pathway (RCP) 8.5 scenario (van Vuuren et al. 2011). To generate time-varying SST and sea ice histories consistent with this forcing scenario for 2015-2100 we conducted a separate nine-member ensemble simulation of the GISS model (using the same historical and RCP8.5 forcings) in which the ocean was represented as a $65-\mathrm{m}-$ deep mixed layer with fixed horizontal heat transports (a $q$-flux configuration). Because of the absence of ocean dynamics, the spread across members in the $q$-flux ensemble was small, and nine members were considered sufficient to capture the forced response. From this $q$-flux ensemble, we separately estimated trends in SSTs and (where applicable) sea ice concentrations for each month separately from 2015 to 2100 using a 24-yr locally weighted scatterplot smoothing (lowess) spline. We used a lowess spline, rather than a simple best-fit linear regression, to account for nonlinearities related to the late twenty-first-century disappearance of sea ice at some high-latitude locations. The $q$-flux ensemble-average lowess estimated trends were then superimposed on the observed variability of linearly detrended (applied to each month separately) HadISST SSTs and sea ice from 1915 to 2000 to create a new synthetic SST and sea ice record to force the GISS-SST ensemble from 2015 to 2100.

The imposed temperature trends on the SST forcing dataset caused widespread warming in all ocean basins, amplified at high-latitude regions lacking perennial sea ice (Fig. 1, top panel; shown for boreal winter, December-February, the main season of ENSO variability). The decadal-average SST pattern associated with the historical drought period is largely preserved in the future, when comparing anomalies calculated relative to contemporaneous climatologies (Hist-DRGHT: 1948-57, calculated relative to 1935-70; Fut-DRGHT: 2048-57, calculated relative to 2035-70) (Fig. 1, bottom two panels). Both periods are characterized by coolerthan-average conditions throughout the central and eastern tropical Pacific, as well as cooler conditions in the Indian Ocean and tropical Atlantic. Global-average surface air temperatures in the ensemble average increased by $\approx 5.4 \mathrm{~K}$ above the 500 -yr average from the preindustrial simulation at the end of the twenty-first century (average over 2090-2100) (Fig. 2, top panel),

\section{Warming Trend, DJF (2015-2100)}

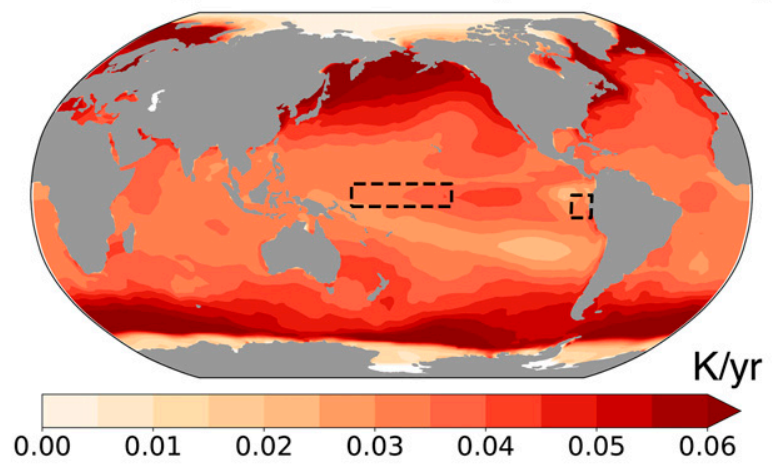

Decadal DJF SST Anomalies

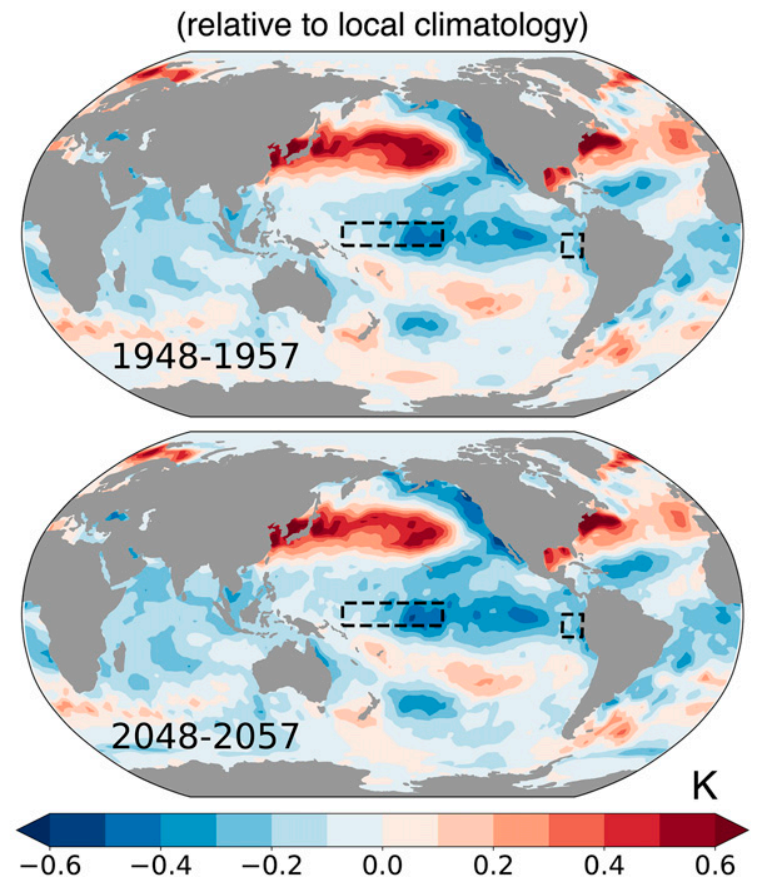

FIG. 1. (top) Linear trend $\left(\mathrm{K} \mathrm{yr}^{-1}\right)$ in December-February (DJF) SSTs from 2015 to 2100. (bottom) DJF SST anomalies during Hist-DRGHT (1948-57, calculated relative to 1935-70) and Fut-DRGHT (2048-57, calculated relative to 2035-70). Dashed areas indicate the Niño- $4\left(5^{\circ} \mathrm{N}-5^{\circ} \mathrm{S}, 160^{\circ} \mathrm{E}-150^{\circ} \mathrm{W}\right)$ and Niño- $1+2$ $\left(0^{\circ}-10^{\circ} \mathrm{S}, 90^{\circ}-80^{\circ} \mathrm{W}\right)$ regions.

comparable to the $\approx 5$-K warming by 2100 in the NCAR Large Ensemble, which also used RCP8.5 (Kay et al. 2015). Comparing the two drought periods, ensembleaverage global temperature anomalies for 1948-57 were $+0.27 \mathrm{~K}$ warmer than the preindustrial $500-\mathrm{yr}$ mean and for $2048-57$ were $+2.92 \mathrm{~K}$ warmer. Because of uneven warming between the central (Niño-4 region; $5^{\circ} \mathrm{N}-5^{\circ} \mathrm{S}, 160^{\circ} \mathrm{E}-150^{\circ} \mathrm{W}$ ) and eastern (Niño-1+2 region; $0^{\circ}-10^{\circ} \mathrm{S}, 90^{\circ}-80^{\circ} \mathrm{W}$ ) tropical Pacific in the $q$-flux ensemble, there is a general increase in the SST gradient 

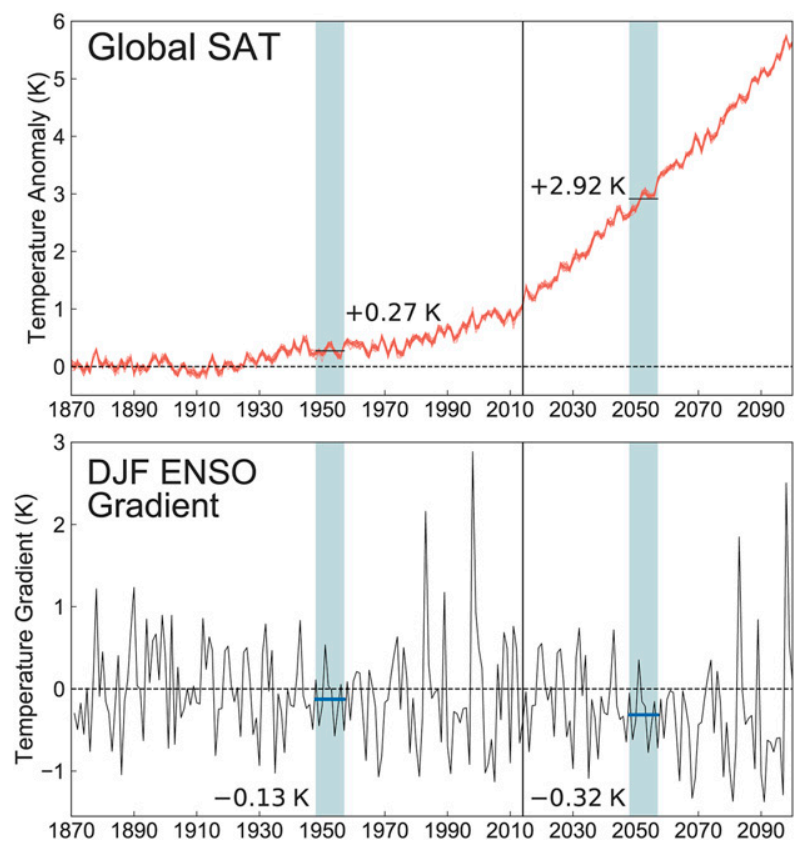

FIG. 2. (top) Annual-average global surface air temperature anomalies for all 20 members in the GISS-SST ensemble. Each red line represents a different ensemble member. Intervals for HistDRGHT (1948-57) and Fut-DRGHT (2048-57) are shaded in light blue, with the global ensemble-average temperature anomaly for each time period indicated. (bottom) ENSO gradient during DJF, calculated as Niño-1+2 SST anomalies minus Niño-4 SST anomalies. Vertical lines indicate the transition between the historical (1870-2014) and RCP8.5 (2015-2100) forcing intervals.

across the eastern tropical Pacific (Fig. 2, bottom panel). This is generally contrary to other model-based work that suggests this gradient should weaken with warming (Yeh et al. 2018), and is possibly a consequence of using a $q$-flux thermodynamic ocean that does not allow for changes in ocean heat transports or dynamics. The result is a slightly stronger decadal mean ENSO forcing during 2048-57 compared to 1948-57, though year-toyear SST variability is still well preserved.

As with all standard simulations using ModelE, the GISS-SST ensemble includes irrigation as an additional anthropogenic forcing (Cook et al. 2015b; Puma and Cook 2010). Irrigation is applied as a seasonally varying water flux to the vegetated areas of irrigated grid cells using a historical dataset of irrigation water demand (IWD, the gross amount of water applied to the grid cell) (Wisser et al. 2010). The IWD dataset is constructed from observations of global areas equipped for irrigation and calculations of water requirements using an offline hydrologic model forced with observed climate. This means that, unlike in many other climate models (e.g., Oleson 2013), IWD in ModelE is prescribed, and not prognostically calculated.
From 1900 to 2005, historically varying irrigation rates in the GISS-SST ensemble are prescribed according to the Wisser et al. (2010) IWD dataset, with values for the nineteenth century (1870-99) linearly extrapolated back in time from early-twentieth-century values. In this dataset (and thus the GISS-SST ensemble), irrigation rates steadily increase in time over the twentieth century, with the rate of intensification accelerating in most irrigated regions after 1950. From 2006 to 2100, irrigation was fixed in time (set constant) and set equal to 2004 irrigation rates, a scenario that effectively assumes no expansion or intensification of irrigation over the twenty-first century. Irrigation water requirements are expected to increase in the future as warmer temperatures increase evaporative losses and shift precipitation patterns (Döll 2002), but meeting these higher demands for many regions will likely be difficult (Elliott et al. 2014). Indeed, irrigation expansion has slowed substantially in recent decades (Wada et al. 2013), and land, water, and infrastructure limitations are expected to inhibit the future expansion or intensification of irrigation in most areas (Elliott et al. 2014; Faurès et al. 2002; Turral et al. 2011). The fixed twenty-first-century irrigation rates used in GISS-SST therefore represent one plausible future irrigation scenario. We acknowledge, however, that future drought impacts may be lessened or amplified depending on whether irrigation increases or decreases in the future. More details on how irrigation is represented in ModelE can be found in Puma and Cook (2010) and Cook et al. (2015b).

Warm season [April-September (AMJJAS)] differences in IWD between the two drought periods are shown in Fig. 3. Irrigation intensities and areas are both higher during Fut-DRGHT (2048-57) compared to Hist-DRGHT (1948-57). This is because IWD during Fut-DRGHT is fixed at 2004 irrigation values, which, because of the intensification and expansion of irrigation over the latter half of the twentieth century, are higher than the mid-twentieth-century irrigation rates used for Hist-DRGHT. These changes mostly involve intensification of irrigation in California and an expansion and intensification of irrigation across the southern and central plains and Southwest. (All simulations in the GISS-SST ensemble are freely available from http:// dester.ldeo.columbia.edu:81/SOURCES/.NASA/.)

\section{b. Analyses}

In the GISS-SST ensemble, we compared drought anomalies between two time periods with analogous SST forcing (1948-57, Hist-DRGHT; 2048-57, FutDRGHT), focused on three main regions (black dashed boxes in Fig. 3): the Southwest United States (SWUS; $28^{\circ}-37^{\circ} \mathrm{N}, 122^{\circ}-104^{\circ} \mathrm{W}$ ), the southern plains 


\section{Irrigation Water Demand (AMJJAS)}
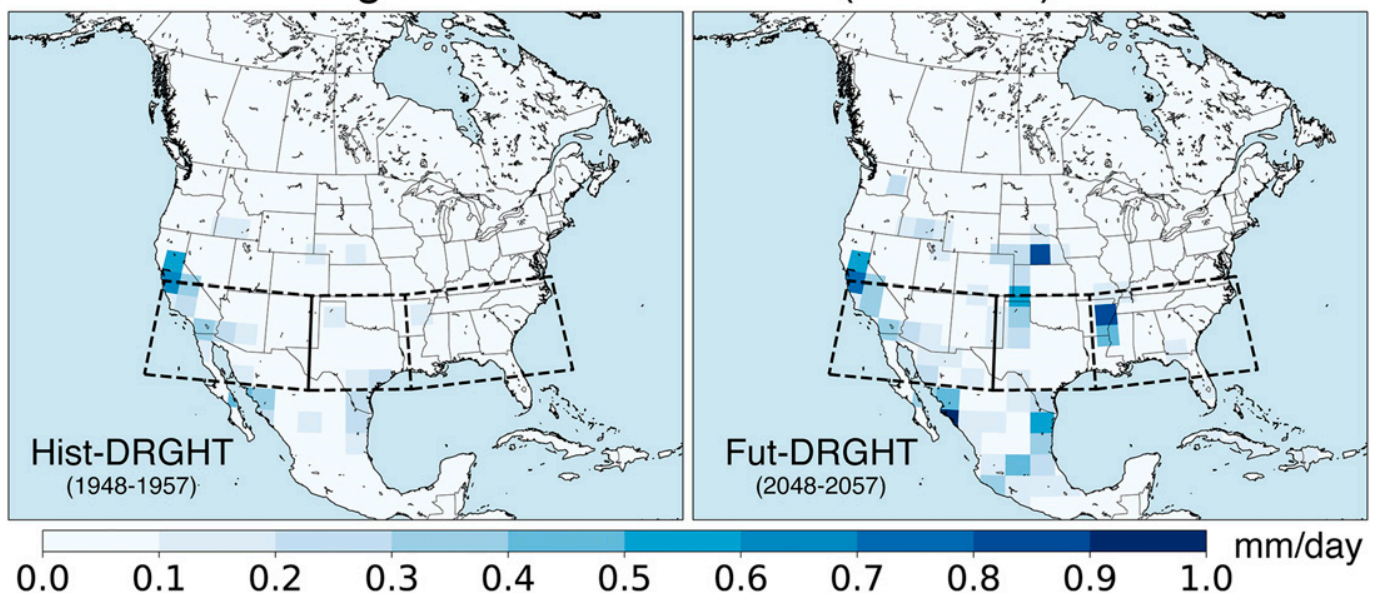

FIG. 3. Average warm season (AMJJAS) IWD in the GISS-SST ensemble during the two drought intervals. As noted in the text, irrigation rates in ModelE are prescribed according to historically varying datasets and are not calculated prognostically within the model.

(SPLA; $28^{\circ}-37^{\circ} \mathrm{N}, 104^{\circ}-93^{\circ} \mathrm{W}$ ), and the Southeast United States (SEUS; $28^{\circ}-37^{\circ} \mathrm{N}, 93^{\circ}-75^{\circ} \mathrm{W}$ ). We considered climate anomalies during the water year, defined for the United States as October from the previous calendar year through September of the current calendar year. Drought and water resource analyses commonly use the water year (e.g., Diaz and Wahl 2015) instead of the calendar year to account for changes in winter and spring moisture anomalies (e.g., precipitation, snow) that can carry forward into the growing season and summer (via runoff, streamflow, and soil moisture), when demand is highest. We separately evaluated the "cold season" [October-March; (ONDJFM)] and "warm season" (AMJJAS) to account for the seasonally varying importance of different processes (e.g., strength of SST teleconnections, magnitude of evaporative demand). Model simulated precipitation deficits during Hist-DRGHT are validated using the latest version (v8) of the $0.25^{\circ}$ global monthly (1891-2016) precipitation grids from the Global Precipitation Climatology Centre (GPCC; Schneider et al. 2014, 2018). For most analyses, anomalies are defined using the same 30-yr-average baseline calculated from 1891 to 1920. This is the earliest 30-yr interval in the GPCC dataset, and we chose this as our main baseline period because 1) it represents the closest period to the preindustrial era in the GPCC dataset, before major anthropogenic forcings (e.g., greenhouse gases, aerosols, irrigation) begin to accelerate, and 2) it is an interval when SST-forced drought variability over North America was relatively weak and decadal length droughts (like the 1950s drought) were largely absent. We do not use separate baselines for analyzing the two drought periods because, ultimately, we wished to evaluate how the SSTforced drought would change with warming. Given this goal, using the same baseline for evaluating both 1948-57 and 2048-57 is most appropriate. Significant differences between the two drought periods are assessed using the nonparametric two-sided Kolmogorov-Smirnov test.

\section{Results and discussion}

\section{a. Precipitation}

Uncertainties in model projections of precipitation are typically higher than for other climate variables (Cook et al. 2018; Knutti and Sedlacek 2013). Given that our analysis is based on a single climate model, it is therefore useful to compare the precipitation response in ModelE to other models under the same forcing. Here, we compare the ensemble-mean seasonal precipitation response in the GISS-SST ensemble to an ensemble of models from the CMIP5 database using historical (CMIP5) and RCP8.5 forcings (Fig. 4). The two ensembles are not completely analogous (e.g., GISS-SST uses the same prescribed SST forcing for all ensemble members while simulations in this CMIP5 ensemble use fully coupled prognostic ocean models), but such a comparison should provide some broad context for the GISS model response. At the continental scale, both GISS-SST and CMIP5 show similar patterns, including wetting at high latitudes and drying across Mexico and the southern United States, especially during the cold season (OND and JFM) and in spring (AMJ). Many patterns are also consistent across the two ensembles during the summer (JAS), including the 


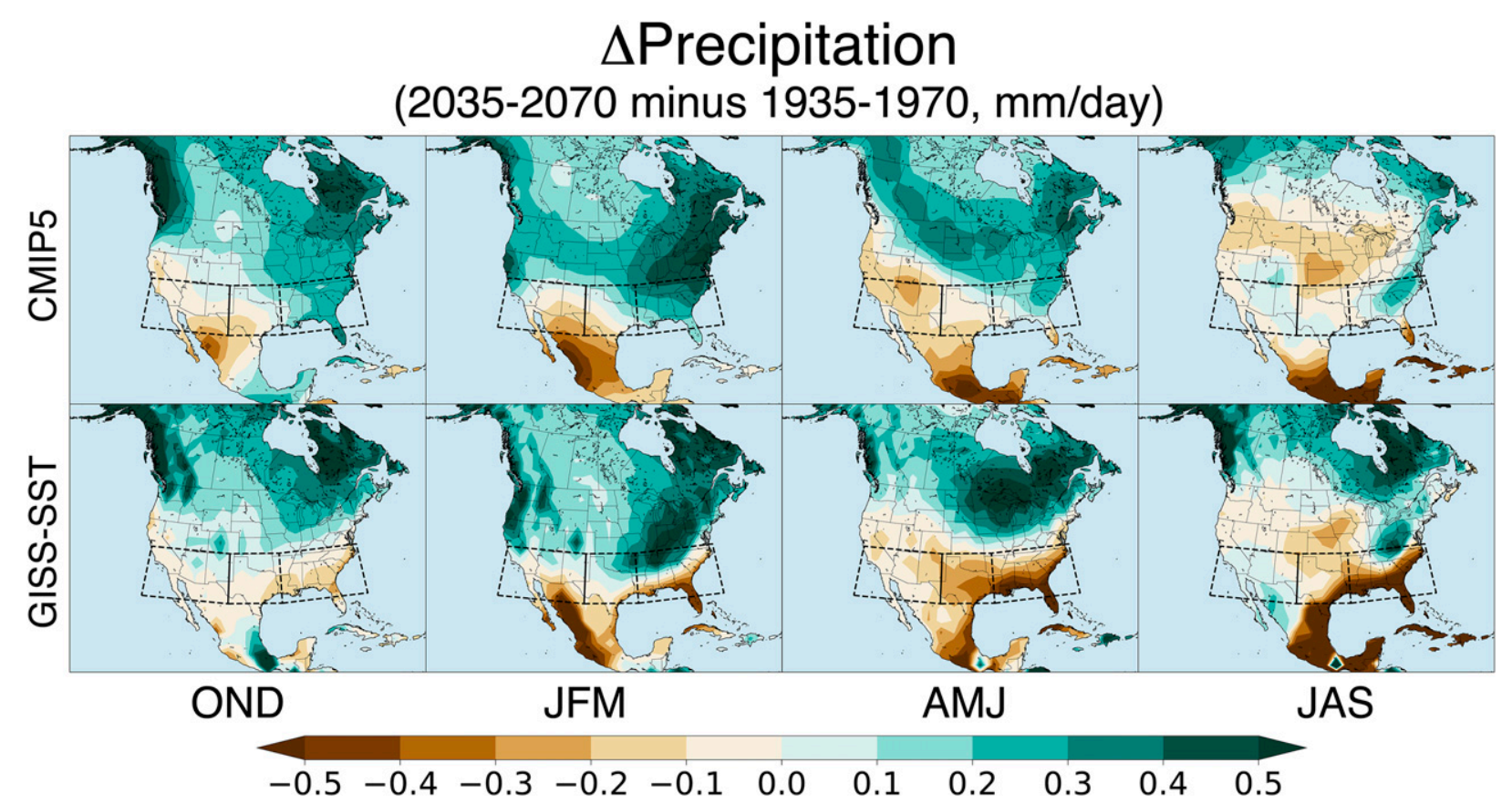

FIG. 4. Seasonal changes (2035-70 minus 1935-70) in precipitation from 23 models in (top) the CMIP5 ensemble (continuous historical plus RCP8.5 scenarios) and (bottom) the GISS-SST ensemble. The two time intervals were chosen to include the two drought intervals of interest in this study. The CMIP5 ensemble includes one member per model from the following models: ACCESS1.0, ACCESS1.3, BCCCSM1.1, BCC-CSM1.1-M, BNU-ESM, CCSM4, CESM1-BGC, CESM1-CAM5, CNRM-CM5, CanESM2, GFDL-CM3, GFDL-ESM2G, GFDL-ESM2M, GISS-E2-H, GISS-E2-R, HadGEM2-CC, HadGEM2-ES, INMCM4, MIROC5, MIROC-ESM, MIROC-ESM-CHEM, NorESM1-M, and NorESM1-ME.

drying in the central United States and Mexico, and wetting in the Southwest and across high northern latitudes. Some minor regional differences are also apparent. For example, while the spring drying in CMIP5 is centered over the Southwest and California, the main center of drying in GISS-SST during this season is over Texas and the Southeast. Similarly, summer season drying over the Pacific Northwest in CMIP5 is not produced in GISS-SST, and over Mexico GISS-SST dries more in the east during spring and summer compared to CMIP5. By far, the single largest difference in the two ensembles is over the Southeast. In CMIP5, this region gets wetter in all seasons, except over Florida, which dries in the spring and summer. This is a sharp contrast to GISS-SST, which shows large declines in precipitation across the Southeast in all seasons, especially along the coast.

During the 1950s drought itself, GPCC precipitation shows extensive cold season precipitation deficits across the southern United States, persisting into the warm season over New Mexico, Texas, and much of the Southeast (Fig. 5). Wet anomalies, conversely, occurred across much of the Pacific Northwest and the central Southeast during the cold season. While the relatively coarse resolution of the GCM precludes the ability to capture finer-scale features in the GPCC dataset, the model does broadly reproduce many of the large-scale precipitation anomaly patterns in the ensemble average, especially during the cold season. For the same time period (1948-57, Hist-DRGHT), the GISS-SST ensemble replicates the widespread drying across the Southwest and southern plains and wet anomalies during this season in the Pacific Northwest. The model has more difficulty reproducing observed precipitation anomalies during the warm season. In this season, drying in the model still occurs over Texas and the southern plains, but with precipitation deficits centered too far east compared to observations. Anomalies in the ensemble average ultimately represent the forced response in the model after random internal atmospheric variability (which is different in each ensemble member) has been averaged out. Conversely, the observations reflect some mixture of SST-forcing and internal atmospheric variability, and so are not exactly comparable to the ensemble-average model response. Further, teleconnection strength between SSTs in the tropical Pacific and precipitation over North America tends to weaken into the warm season (Trenberth et al. 1998), making it likely that internal atmospheric variability contributes even more strongly to the precipitation deficits and 


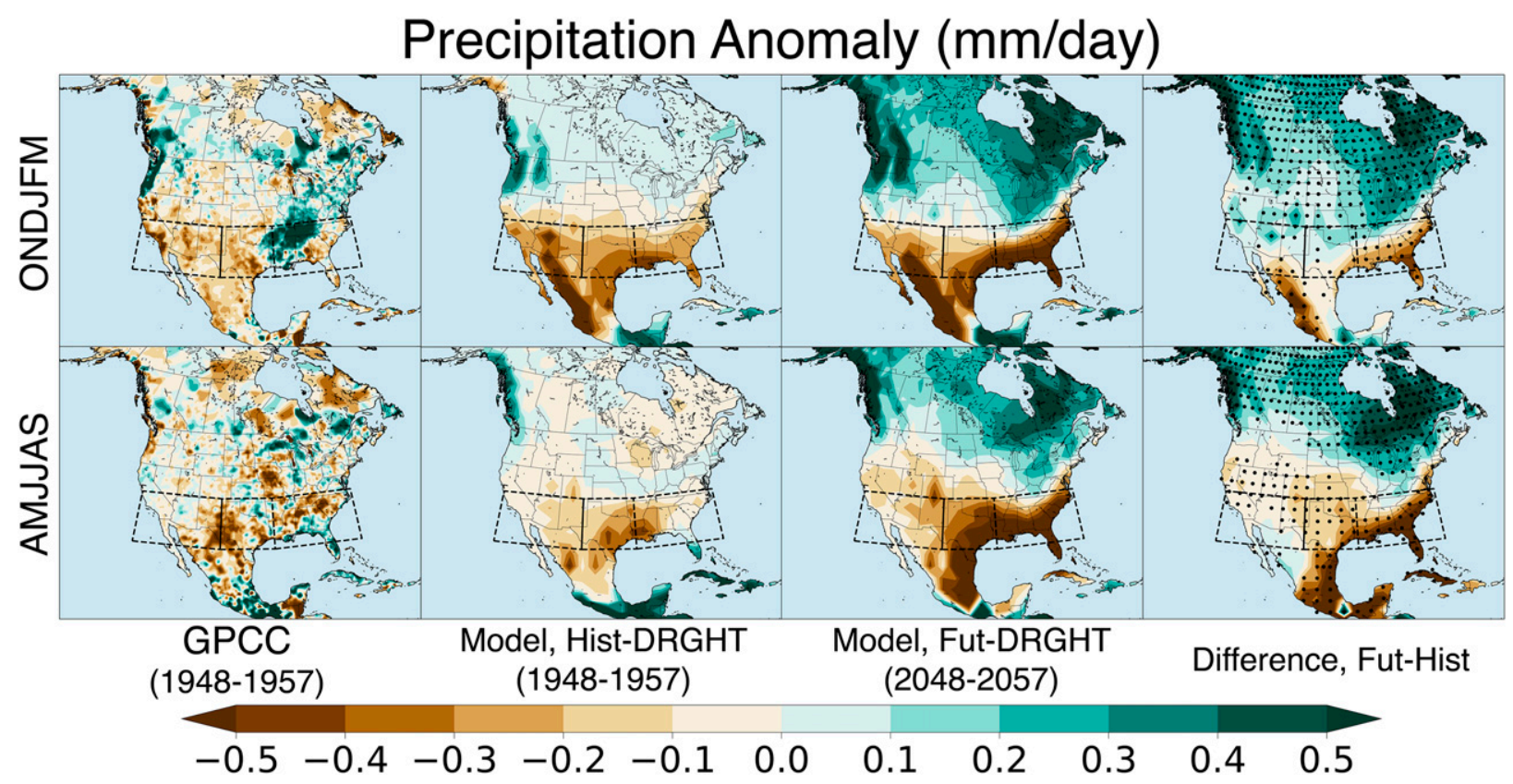

FIG. 5. Observed (GPCC) and modeled (ensemble average) (top) cold season (ONDJFM) and (bottom) warm season (AMJJAS) precipitation anomalies $\left(\mathrm{mm} \mathrm{day}^{-1}\right)$ during the Hist-DRGHT (1948-57) and Fut-DRGHT (2048-57) intervals, relative to the 1891-1920 baseline average. Simulated Hist-DRGHT precipitation anomalies are broadly similar to observations (GPCC), with deficits across the Southwest, Mexico, southern plains, and Southeast United States, especially during the cold season. (right) Differences between the two drought periods (Fut-DRGHT minus Hist-DRGHT), showing amplified drying in Fut-DRGHT over the Southeast in both seasons and the southern plains and Southwest in the warm season, along with reduced deficits over much of the Southwest in the cold season. Areas where precipitation anomalies are significantly different between the two drought periods (based on a two-sided Kolmogorov-Smirnov test, $p \leq 0.05)$ are indicated by the black stippling.

surpluses during the warm season. Given these caveats, we conclude that the GISS-SST ensemble overall is able to adequately reproduce the SST-forced precipitation anomalies over North America during the 1948-57 drought.

The spatial extent of precipitation anomalies during Fut-DRGHT is broadly similar to Hist-DRGHT, especially during the cold season, but with some significant differences in intensity. During the cold season in FutDRGHT, precipitation deficits are reduced (but not reversed) across the Southwest and southern plains, much of the northern half of North America becomes significantly wetter, and deficits are intensified in the Southeast United States and northwest Mexico. Precipitation reductions in Fut-DRGHT relative to HistDRGHT are most widespread in the warm season, affecting eastern Mexico, the western United States, the southern and central plains, and the Southeast United States. Precipitation also increases significantly across Canada and the Northeast United States in the warm season. The shifts in precipitation anomalies between Hist-DRGHT and Fut-DRGHT are likely due to either changes in the strength and character of the underlying ENSO teleconnections or GHG-forced precipitation trends. There is broad evidence that warming can lead to changes in SST teleconnections and the magnitude of the associated climate anomalies (e.g., Bonfils et al. 2015; Fasullo et al. 2018; Power and Delage 2018; Yeh et al. 2018), even in the absence of changes in ocean dynamics or atmospheric circulation (Seager et al. 2012; Yeh et al. 2018). Over North America, this may manifest as an eastward and northward shift of ENSO teleconnection patterns (Meehl et al. 2007; Stevenson 2012). Climate change is also expected to cause regional shifts in precipitation, though the sign, magnitude, and robustness of the response varies strongly by region and season, with large uncertainties across models (Knutti and Sedlacek 2013). For North America, GHG forcing is expected to cause widespread increases in precipitation during the cold season, as well as pronounced precipitation declines localized over the Southwest in the spring (March-May) and across the western United States in the summer (June-August) (Seager et al. 2013; Ting et al. 2018).

To isolate changes associated with shifts in ENSO teleconnections, we linearly detrended precipitation, the SST anomalies over the Niño-3.4 region $\left(5^{\circ} \mathrm{N}-5^{\circ} \mathrm{S}\right.$, $170^{\circ}-120^{\circ} \mathrm{W}$ ), and $200-\mathrm{hPa}$ geopotential heights in the 


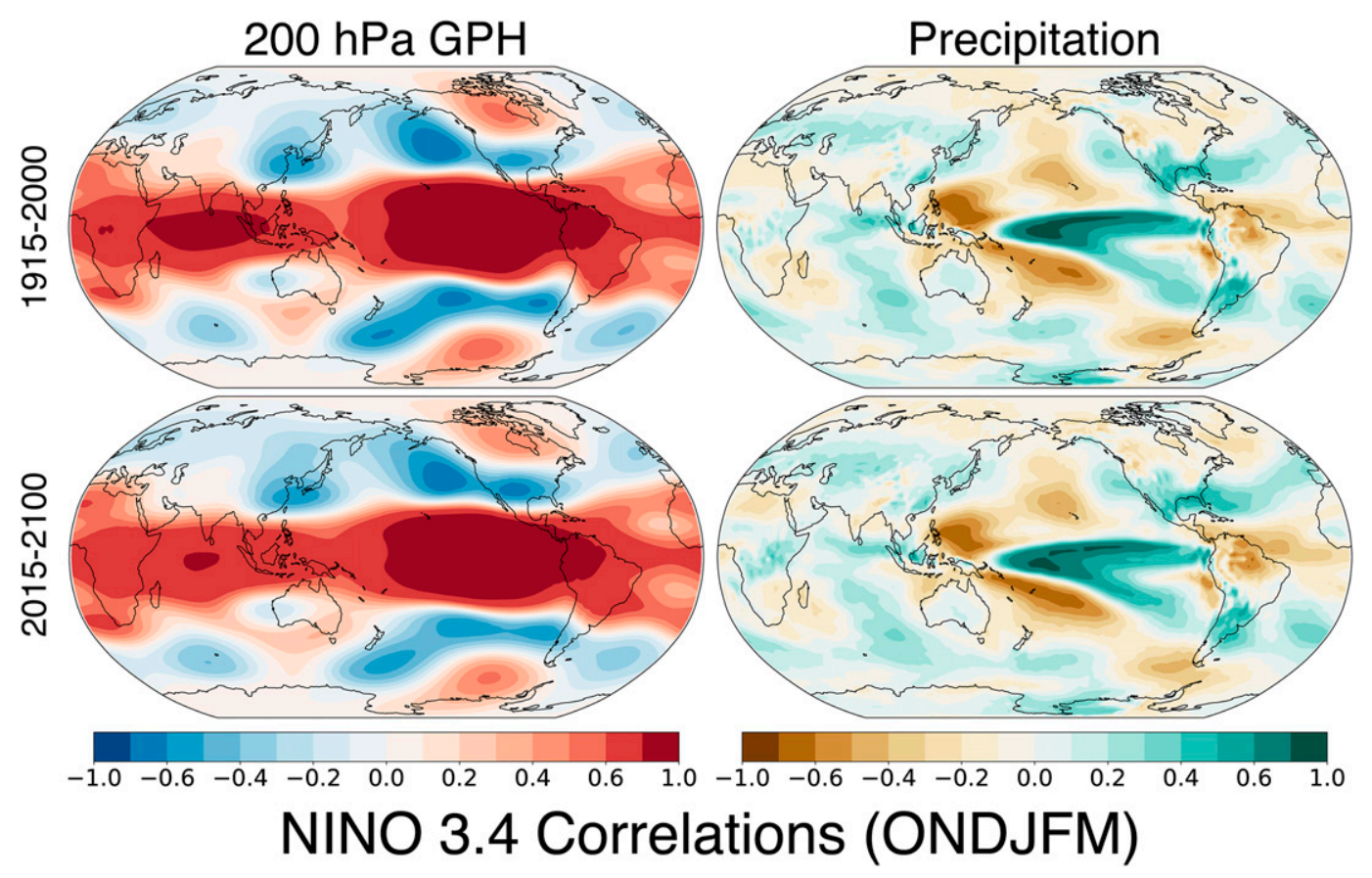

FIG. 6. Ensemble-median Pearson's correlations calculated between linearly detrended Niño-3.4 index and (left) 200-hPa geopotential heights and (right) precipitation during the cold season for two time periods: (top) 1915-2000 and (bottom) 2015-2100.

GISS-SST ensemble over two time periods: 1915-2000 and 2015-2100. Ensemble-average cold season correlations between the detrended Niño-3.4 index and geopotential heights and precipitation show broadly similar spatial patterns between the two periods, despite significantly different levels of GHG forcing (Fig. 6). Negative correlations with geopotential heights strengthen slightly over the southern United States in the twenty-first century, and precipitation correlations weaken over the southwestern United States and strengthen slightly over the southeastern United States. Composites of these detrended precipitation anomalies calculated for the two drought periods, which we interpret as the change in precipitation independent of long-term GHG-forced trends, do show some significant differences in line with these teleconnection shifts (Fig. 7). These include amplified precipitation deficits over the southeastern United States in both seasons, and ameliorated deficits over the southwestern United States in the cold season and the southern plains during the warm season (these latter changes are largely insignificant, except over the southernmost part of coastal Texas). The magnitude of these anomalies is relatively small compared to the full differences between nondetrended Hist-DRGHT and Fut-DRGHT precipitation (Fig. 5), indicating that GHG-forced trends are likely the dominant driver of precipitation differences between the two droughts.
These results are broadly consistent with other analyses and models, which also demonstrate that changes in precipitation associated with shifts in ENSO teleconnections are likely to be small relative to GHGforced changes in the mean state (e.g., Bonfils et al. 2015; Power and Delage 2018; Yeh et al. 2018).

\section{b. Runoff and soil moisture}

Runoff deficits are widespread across the southern United States and Mexico during both droughts (Fig. 8), intensifying in Fut-DRGHT over southeastern Texas and the Southeast United States in both seasons and in New Mexico during the warm season. For much of the southern United States, however, differences in runoff between the two droughts are insignificant, especially during the cold season. North of these regions, FutDRGHT is characterized by widespread seasonal shifts in runoff (increasing in the cold season and decreasing in the warm season) over Canada and high-elevation areas in the western United States. This likely reflects GHGforced increases in cold season total precipitation, as well as warmer temperatures causing a shift from snow to rain and an earlier melt of the seasonal snowpack.

Averaged over our three regions of interest, we compare month-by-month precipitation and runoff anomalies between Hist-DRGHT and Fut-DRGHT over the course of the water year (Fig. 9). Consistent 


\section{Detrended Prec. Anomaly (mm/day)}
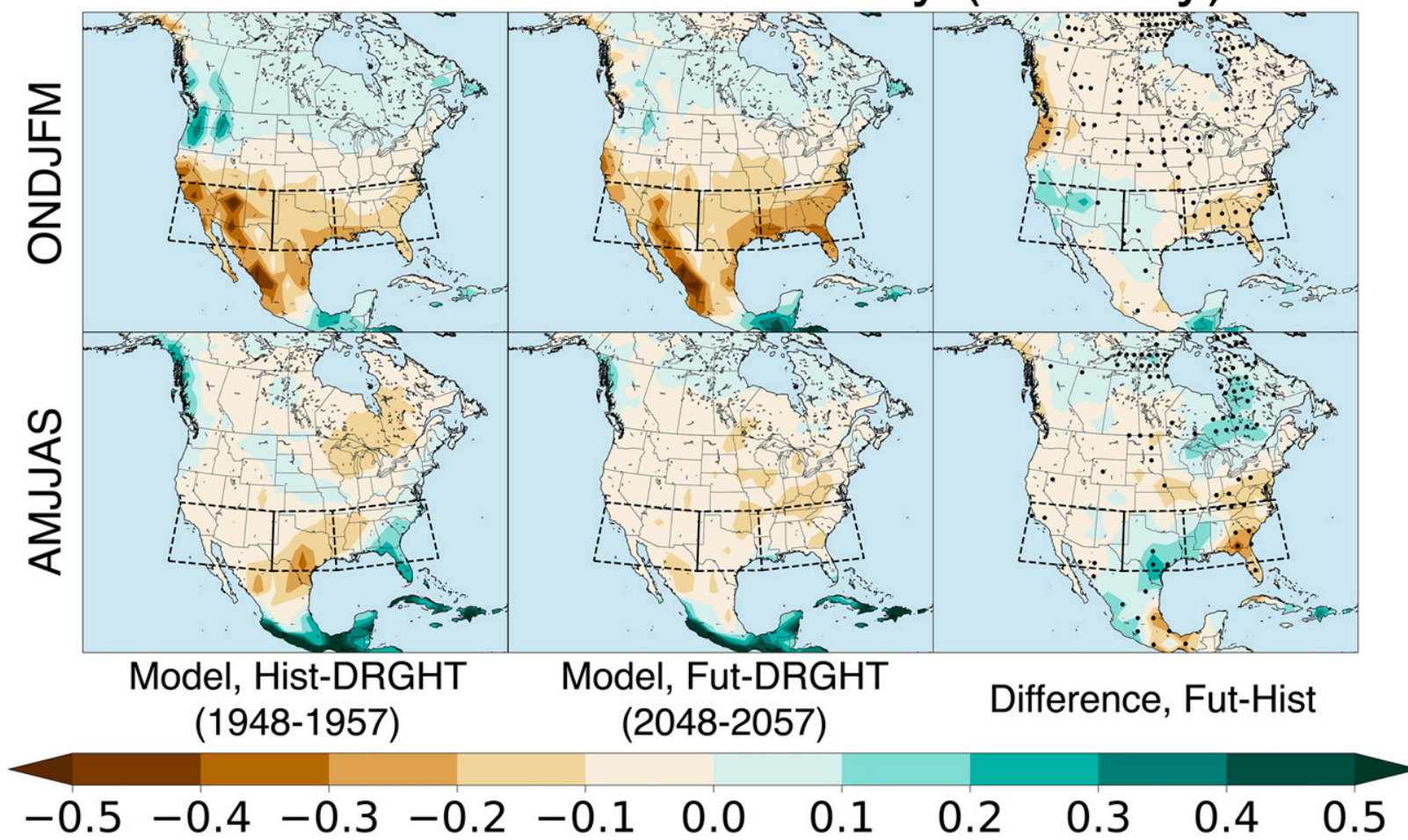

FIG. 7. Ensemble-average detrended precipitation anomalies during (left) Hist-DRGHT (linear trend from 1915 to 2000 removed) and (center) Fut-DRGHT (linear trend from 2015 to 2100 removed). (right) Difference between the two drought periods (Fut-DRGHT minus Hist-DRGHT), representing the change in precipitation not associated with long-term greenhouse warming. Areas where these precipitation anomalies are significantly different between the two drought periods (based on a two-sided Kolmogorov-Smirnov test, $p \leq$ $0.05)$ are indicated by the black stippling.

with other studies in the literature (Seager et al. 2013; Ting et al. 2018), the strongest and most significant (black dots) future declines in precipitation over SWUS and SPLA occur in the spring (April-May). These seasonal precipitation declines co-occur or precede the main months of runoff declines in these regions during Fut-DRGHT: March-May in SWUS and May-August in SPLA. Over SEUS, precipitation declines in FutDRGHT throughout the year, with largest deficits occurring in the late spring and summer (May-August). Contrary to the other two regions, however, runoff deficits in SEUS are significantly more severe in every month during Fut-DRGHT compared to Hist-DRGHT.

While the runoff differences between Hist-DRGHT and Fut-DRGHT appear broadly in line with the precipitation shifts, other factors (including snowpack storage, evaporative losses, and vegetation responses) can also affect runoff (e.g., Mankin et al. 2018). One metric that can be used to assess whether changes in runoff can be explained solely by changes in precipitation is the runoff ratio (or efficiency). We calculated runoff ratio for Hist-DRGHT and Fut-DRGHT separately, dividing the seasonal average runoff by seasonal average precipitation. If runoff differences between Hist-DRGHT and Fut-DRGHT were due solely to precipitation changes, we would expect the runoff ratio to be the same for both periods. If, however, runoff ratio declines, this means a smaller fraction of precipitation inputs is allocated to runoff, and other processes must be contributing to the shifting surface water balance (e.g., increased evaporative losses).

Averaged across the entire cold season, precipitation, runoff, and the runoff ratio do not change significantly between Hist-DRGHT and Fut-DRGHT for SWUS and SPLA (Fig. 10), in part reflecting precipitation increases in the northern half of these regions that balance out declines in the southern half (Fig. 5). Only SEUS shows significant declines in precipitation, runoff, and the runoff ratio during the cold season. As noted above, the decline in runoff ratio means that, even though precipitation deficits are significantly enhanced over SEUS in Fut-DRGHT, these changes alone are not sufficient to fully explain the magnitude of runoff declines. For the warm season, all three regions show 


\section{Runoff Anomaly (mm/day)}

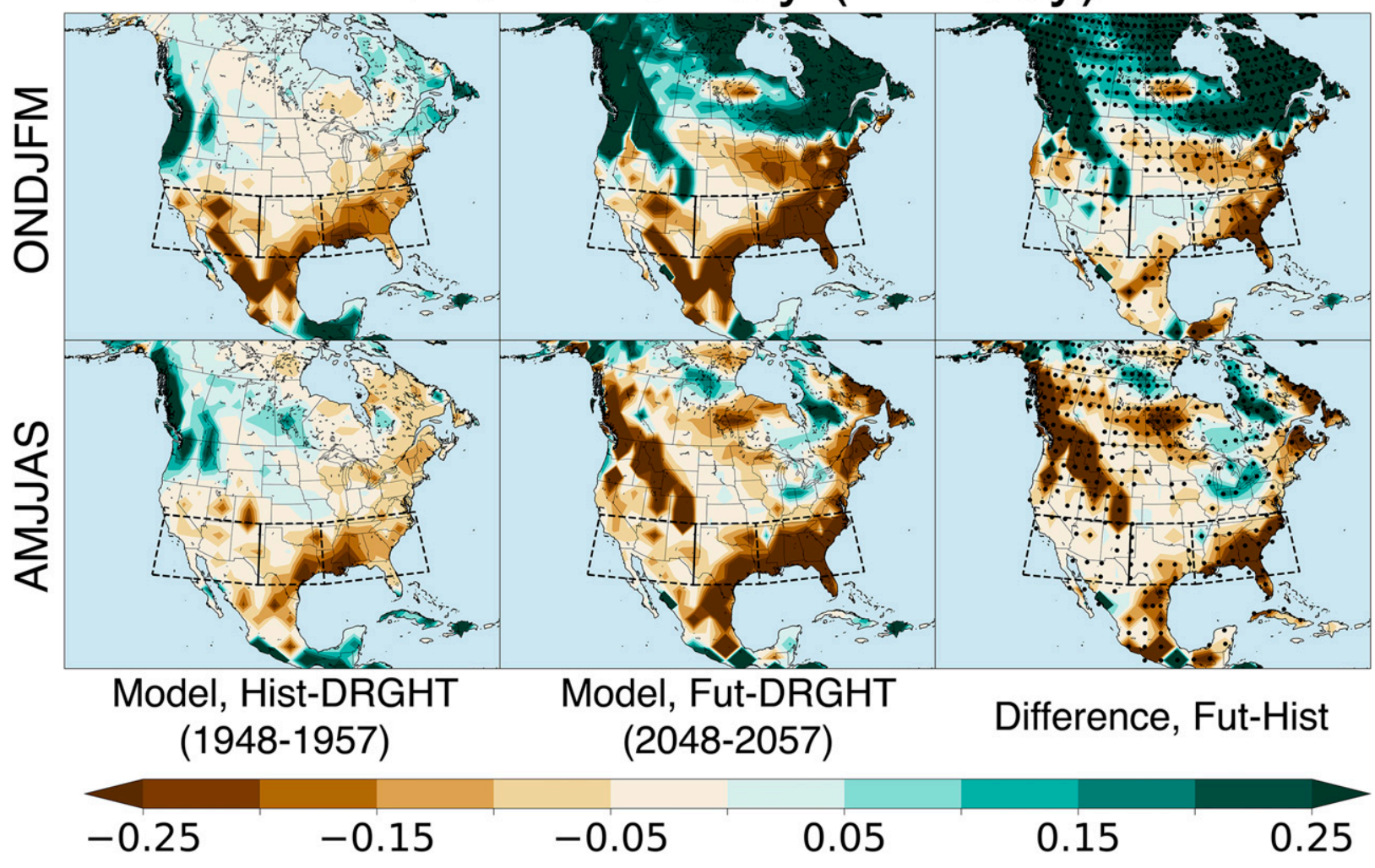

FIG. 8. Ensemble-average (top) cold season (ONDJFM) and (bottom) warm season (AMJJAS) total runoff (combined surface and subsurface) anomalies (mm day ${ }^{-1}$ ) during the (left) Hist-DRGHT (1948-57) and (center) Fut-DRGHT (2048-57) intervals, relative to the 1891-1920 baseline average. (right) Differences between the two drought periods (Fut-DRGHT minus Hist-DRGHT). Areas where these runoff anomalies are significantly different between the two drought periods (based on a two-sided Kolmogorov-Smirnov test, $p \leq$ $0.05)$ are indicated by the black stippling.

significant declines in precipitation and runoff during Fut-DRGHT (Fig. 11), attributable in part to the much more robust precipitation declines during this season. For SPLA, warm season runoff ratio does not change in Fut-DRGHT, suggesting that the enhanced precipitation deficits are the sole driver of runoff declines in this region, contrasting with both SWUS and SEUS, where warm season runoff ratio is significantly reduced.

Warm season soil moisture deficits occur in both drought periods, at the surface (here defined as the top two layers in the soil column, to a depth of $\approx 27 \mathrm{~cm}$ ) and in the root zone (here defined as the top four layers in the soil column, to a depth of $\approx 1 \mathrm{~m}$ ) (Fig. 12). Here, we represent soil moisture anomalies as standardized $z$ scores to allow for direct comparisons of relative changes in soil moisture between the surface layers and deeper in the column. Soil moisture anomalies were relatively more severe in the root zone compared to the surface during Hist-DRGHT, reflecting the importance of the cold season precipitation deficits carrying forward into the warm season in these deeper layers. Soil moisture actually increases in irrigated grid cells during HistDRGHT over California and northern Texas (Fig. 3), with this additional water input compensating for the precipitation deficits.

Compared to precipitation and even runoff, amplified warm season soil moisture deficits are much more widespread in Fut-DRGHT, at the surface and in the root zone. As during Hist-DRGHT, irrigation acts to compensate for and diminish some of the drying, especially in Texas. Even with irrigation, however, the prescribed irrigation inputs are not sufficient to completely buffer the soil moisture in the future. Soil moisture is significantly lower in nearly every grid cell in the three regions across the southern United States, and this drying also extends to much of the rest of North America, especially in surface soil moisture. The result is severe and significant drying in the regional-average soil moisture anomalies for the SWUS, SPLA, and SEUS regions, both at the surface and in the root zone 

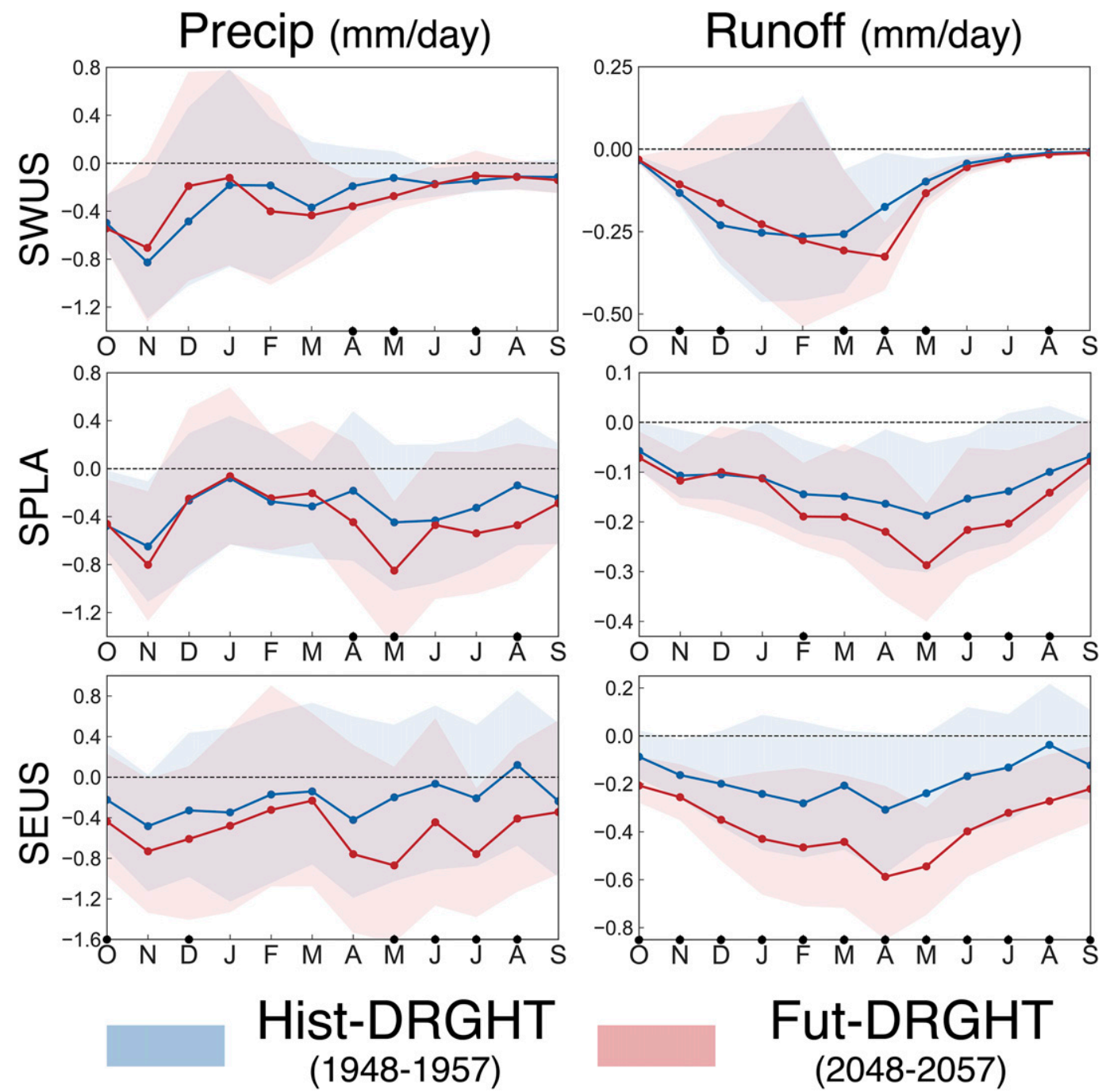

FIG. 9. Ensemble median (solid lines) and interquartile range (shading) for area-averaged (left) precipitation and (right) runoff anomalies from (top) SWUS, (middle) SPLA, and (bottom) SEUS during the two drought periods. Black dots along the $x$ axis indicate months where there are significant $(p \leq 0.05)$ differences between Fut-DRGHT and Hist-DRGHT, based on a two-sided Kolmogorov-Smirnov test.

(Fig. 13). As with runoff, it appears unlikely that the precipitation differences alone between Hist-DRGHT and Fut-DRGHT are sufficient to explain the full amplitude of enhanced soil moisture drying in the future.

\section{c. Evaporative partitioning}

A plausible mechanism for the enhanced surface drying in runoff and soil moisture in Fut-DRGHT is increased evaporative losses. Warming with climate change will increase evaporative demand in the atmosphere (Scheff and Frierson 2014), potentially drawing more moisture from the surface and leaving less water available for runoff or storage in the soils. Such a mechanism has been invoked to explain widespread drying in both soil moisture and runoff in climate model projections for the twenty-first century (Cook et al. 2015a; Dai 2013; Mankin et al. 2017, 2018), and may explain some of the amplified surface drying during FutDRGHT.

To investigate this, we compared changes in total water inputs (precipitation plus irrigation) and total evapotranspiration between the two drought periods (left and center panels in Fig. 14). Differences in water inputs closely track the precipitation differences highlighted previously (Fig. 5), indicating that higher prescribed irrigation rates during Fut-DRGHT have limited impacts. Total evapotranspiration increases during the cold season across much of North America, with declines occurring primarily along the Gulf Coast and Florida in the Southeast United States. The biggest differences in 


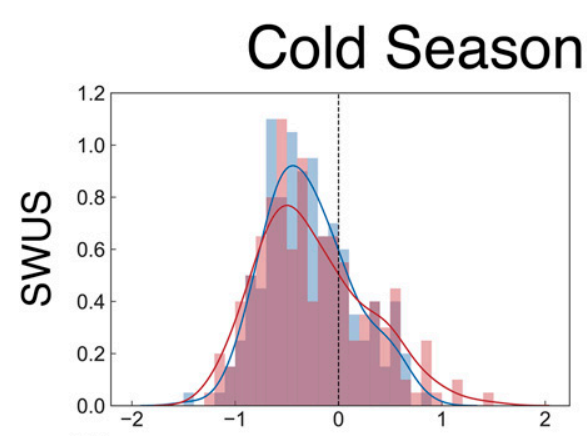

Precipitation \& Runoff (ONDJFM)
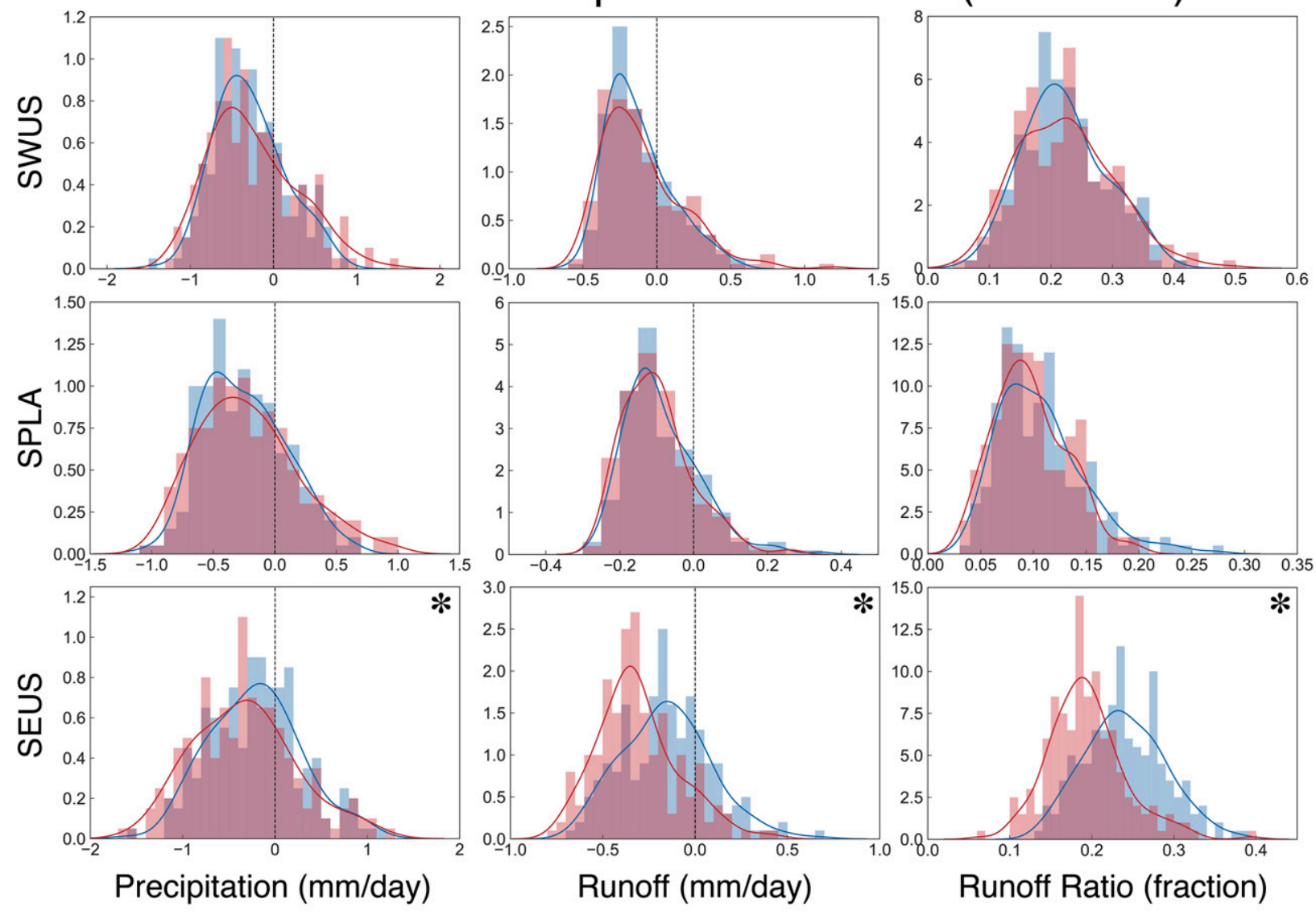

Runoff (mm/day)

Runoff Ratio (fraction)

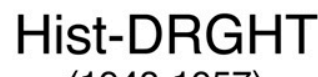

(1948-1957)

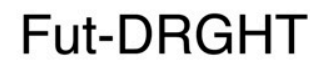

(2048-2057)

FIG. 10. Normalized histograms (bars) and kernel density plots (lines) for cold season (ONDJFM) average (left) precipitation anomalies, (center) runoff anomalies, and (right) runoff ratios, averaged over (top) SWUS, (middle) SPLA, and (bottom) SEUS. Distributions include all years from the Fut-DRGHT and Hist-DRGHT periods (10 in each ensemble member) from all 20 ensemble members $(n=200)$. Black asterisks indicate variables with significant $(p \leq 0.05)$ differences between Fut-DRGHT and Hist-DRGHT, based on a two-sided Kolmogorov-Smirnov test.

evapotranspiration occur in the warm season, however, with widespread increases across most of the northern half of North America and sharp declines in Texas and the Southeast United States.

Evapotranspiration, however, is sensitive to both evaporative demand in the atmosphere and moisture availability at the surface. For example, evapotranspiration may decrease even as demand in the atmosphere increases, if the soils dry to critical levels and less water is available at the surface. The most critical metric to evaluate is instead changes in the evaporative partitioning, defined as evapotranspiration divided by the precipitation plus irrigation total water inputs (right panels in Fig. 14). Here, positive values indicate areas where, in Fut-DRGHT, water inputs are increasingly being allocated to evapotranspiration, resulting in less water available for runoff or soil moisture recharge, even in cases where precipitation either increases or does not change.

Over the SWUS, evaporative partitioning significantly increases over Arizona and New Mexico in both seasons (Fig. 14). Increased precipitation during the cold season compensates for this (Fig. 5), resulting in no significant decline in cold season runoff or the runoff ratio (Fig. 10). During the warm season, however, increased evaporative partitioning combines with reduced precipitation to significantly amplify deficits in runoff (Fig. 11) and soil moisture (Fig. 13) over SWUS. Changes in evaporative partitioning over SPLA are mostly insignificant in both seasons. With previous 


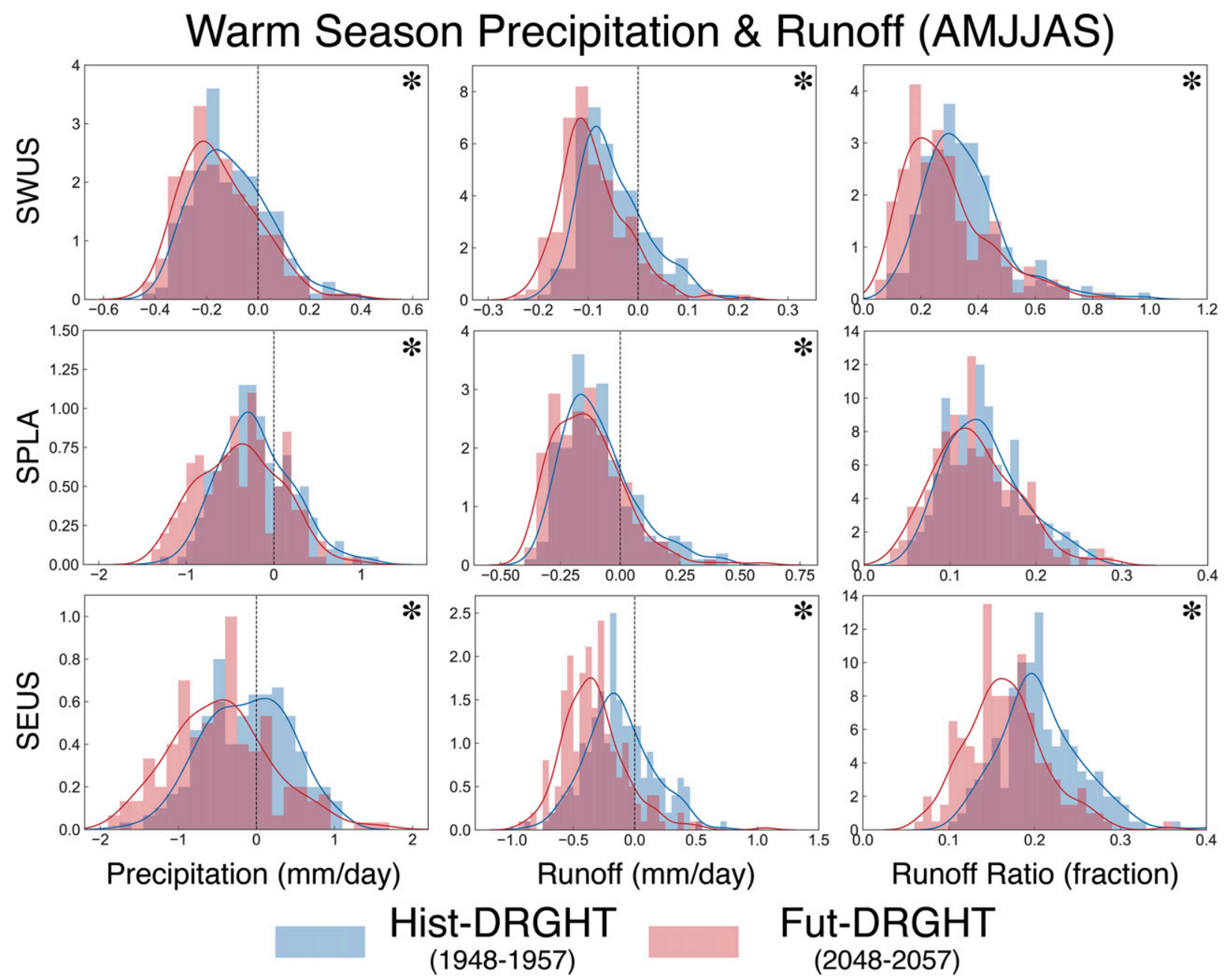

FIG. 11. Normalized histograms (bars) and kernel density plots (lines) for warm season (AMJJAS) average (left) precipitation anomalies, (center) runoff anomalies, and (right) runoff ratios, averaged over (top) SWUS, (middle) SPLA, and (bottom) SEUS. Distributions include all years from the Fut-DRGHT and Hist-DRGHT periods (10 in each ensemble member) from all 20 ensemble members $(n=200)$. Black asterisks indicate variables with significant $(p \leq 0.05)$ differences between Fut-DRGHT and Hist-DRGHT, based on a two-sided Kolmogorov-Smirnov test.

evidence indicating no change in runoff ratio, this strongly suggests that soil moisture and runoff drying over SPLA are driven almost entirely by precipitation declines. Of all three regions, increased evaporative partitioning appears largest, most significant, and most widespread in SEUS, occurring in both seasons and contributing toward enhanced runoff and soil moisture drying that is extant throughout the year.

\section{Conclusions}

Tropical Pacific SSTs are a major driver of hydroclimate variability in North America (Schubert et al. 2016; Seager and Hoerling 2014), including the decadallength 1950s drought, which ranks as one of the worst in the historical record (Hoerling et al. 2009; Quiring and Goodrich 2008; Seager et al. 2005; Winters 2013). Such droughts can be reliably reproduced in many SST-forced GCM experiments (e.g., Seager et al. 2005), including the GISS-SST ensemble. Here we have demonstrated that even modest warming $(+2.92 \mathrm{~K}$ during Fut-DRGHT) would be sufficient to significantly amplify the severity of a drought forced by the same SST patterns as the original 1950s event. Warming intensifies precipitation deficits during the drought across most of the southern United States, especially during the warm season. This drying is a direct consequence of long-term GHG-forced declines in precipitation rather than any shifts in the strength or fidelity of the SST teleconnections. The precipitation drying contributes to increased deficits in runoff 


\section{Soil Moisture Anomaly (z-score, AMJJAS)}

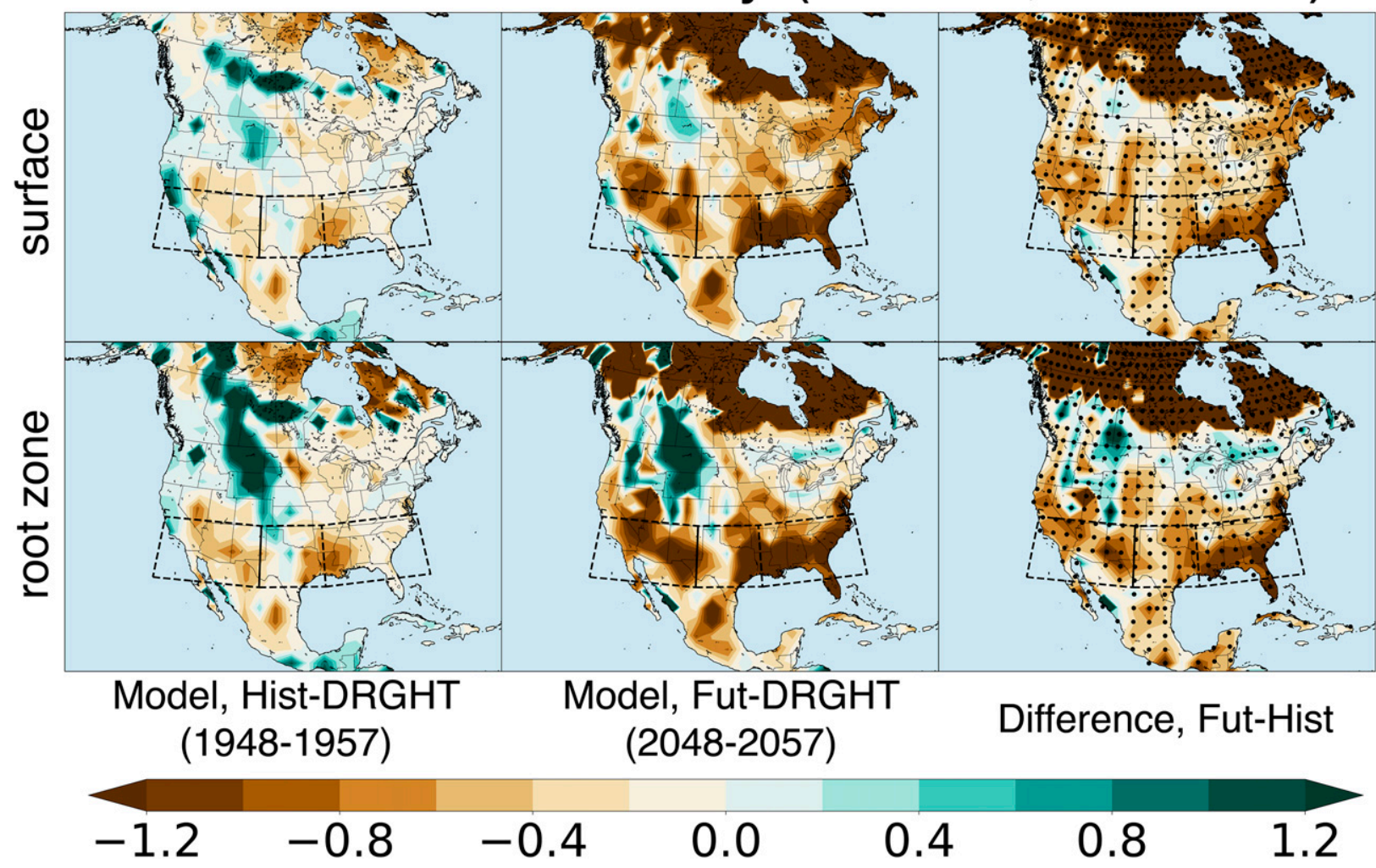

FIG. 12. Ensemble-average warm season (AMJJAS) soil moisture (surface and root zone) anomalies ( $z$ score) during the (left) HistDRGHT (1948-57) and (right) Fut-DRGHT (2048-57) intervals. Standardization to $z$ scores is based on the mean and standard deviation from the 1891-1920 baseline period. (right) Differences between the two drought periods (Fut-DRGHT minus Hist-DRGHT). Areas where soil moisture anomalies are significantly different between the two drought periods (based on a two-sided Kolmogorov-Smirnov test, $p \leq 0.05$ ) are indicated by the black stippling.

and soil moisture, but over the Southwest and Southeast surface drying is further enhanced because warming increases atmospheric moisture demand and evaporative losses from the surface. These results strongly suggest that future warming will likely intensify SST-forced drought impacts on water resources and ecosystems across much of the United States.

Recent drought events provide at least some evidence that the mechanisms identified for Fut-DRGHT in the GISS-SST ensemble are beginning to manifest. While precipitation deficits for these droughts have been mostly attributed to natural variability (Delworth et al. 2015; Lehner et al. 2018; Seager et al. 2015), numerous studies have detailed how anthropogenic warming has contributed toward enhanced deficits in snow (Berg and Hall 2017; Mote et al. 2016, 2018), streamflow (Udall and Overpeck 2017; Woodhouse et al. 2016; Xiao et al. 2018), and soil moisture (Williams et al. 2015) through the same mechanisms noted in the GISS-SST ensemble. A climate change influence on drought in North America is thus already detectable and separable from natural variability, at much lower levels of warming than FutDRGHT. Results from this study are also broadly consistent with other analyses of drought in twenty-firstcentury climate change projections, which also indicate that warming is likely to increase drought severity across much of North America (e.g., Cook et al. 2015a; Mankin et al. 2017; Seager et al. 2013).

As with all studies based on simulations from a single climate model, there are uncertainties that provide important caveats for our results. For example, the Southeast region in GISS-SST experiences some of the strongest and most robust precipitation declines in our simulations, and these changes in precipitation drive much of the increased drought severity in the region. However, this pattern is not consistent with the broader CMIP5 ensemble, which suggests that much of the Southeast may actually get wetter with warming. Notably, simulations of the GISS model in CMIP5 that include a prognostic ocean model produce positive precipitation 


\section{Soil Moisture Anomaly (z-score, AMJJAS)}
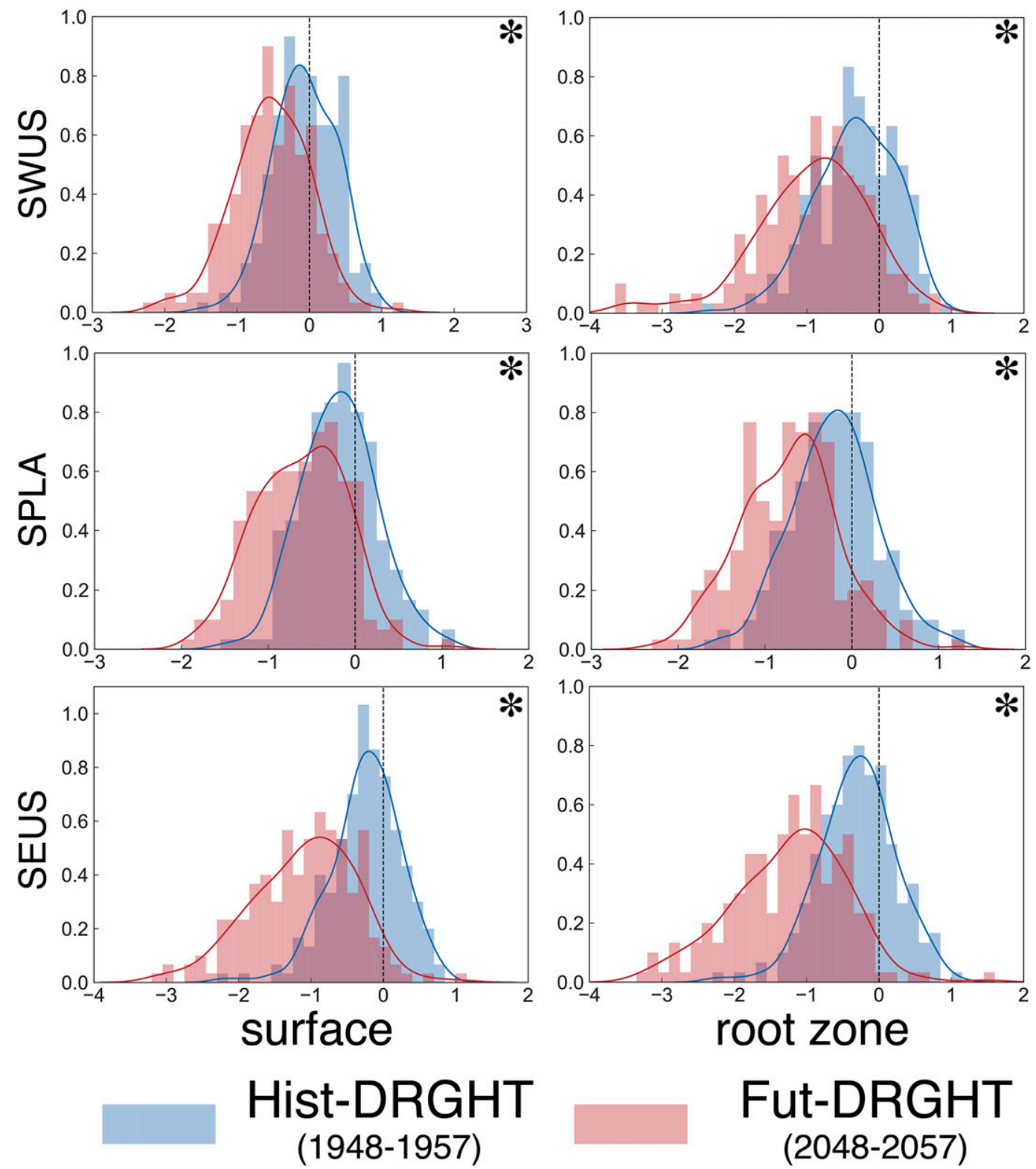

FIG. 13. Normalized histograms (bars) and kernel density plots (lines) for warm season (AMJJAS) (left) surface and (right) root zone soil moisture anomalies, averaged over (top) SWUS, (middle) SPLA, and (bottom) SEUS Distributions include all years from the Fut-DRGHT and Hist-DRGHT periods (10 in each ensemble member) from all 20 ensemble members $(n=200)$. Black asterisks indicate variables where there are significant $(p \leq 0.05)$ differences between Fut-DRGHT and Hist-DRGHT, based on a two-sided Kolmogorov-Smirnov test.

trends over the Southeast that are consistent with the CMIP5 ensemble response (Bishop et al. 2019). This suggests that the precipitation drying in GISS-SST may be a consequence of the prescribed ocean variability and not a response specific to the GISS model itself. Regardless of the cause, this highlights the large uncertainties surrounding precipitation projections in models and the important implications this will have for changes in future drought risk and severity. Even with these uncertainties, however, the surface drought response in runoff and soil moisture is not solely dependent on the model precipitation responses, as in the Southeast and Southwest there is also a clear drying contribution from increased evaporative losses. 


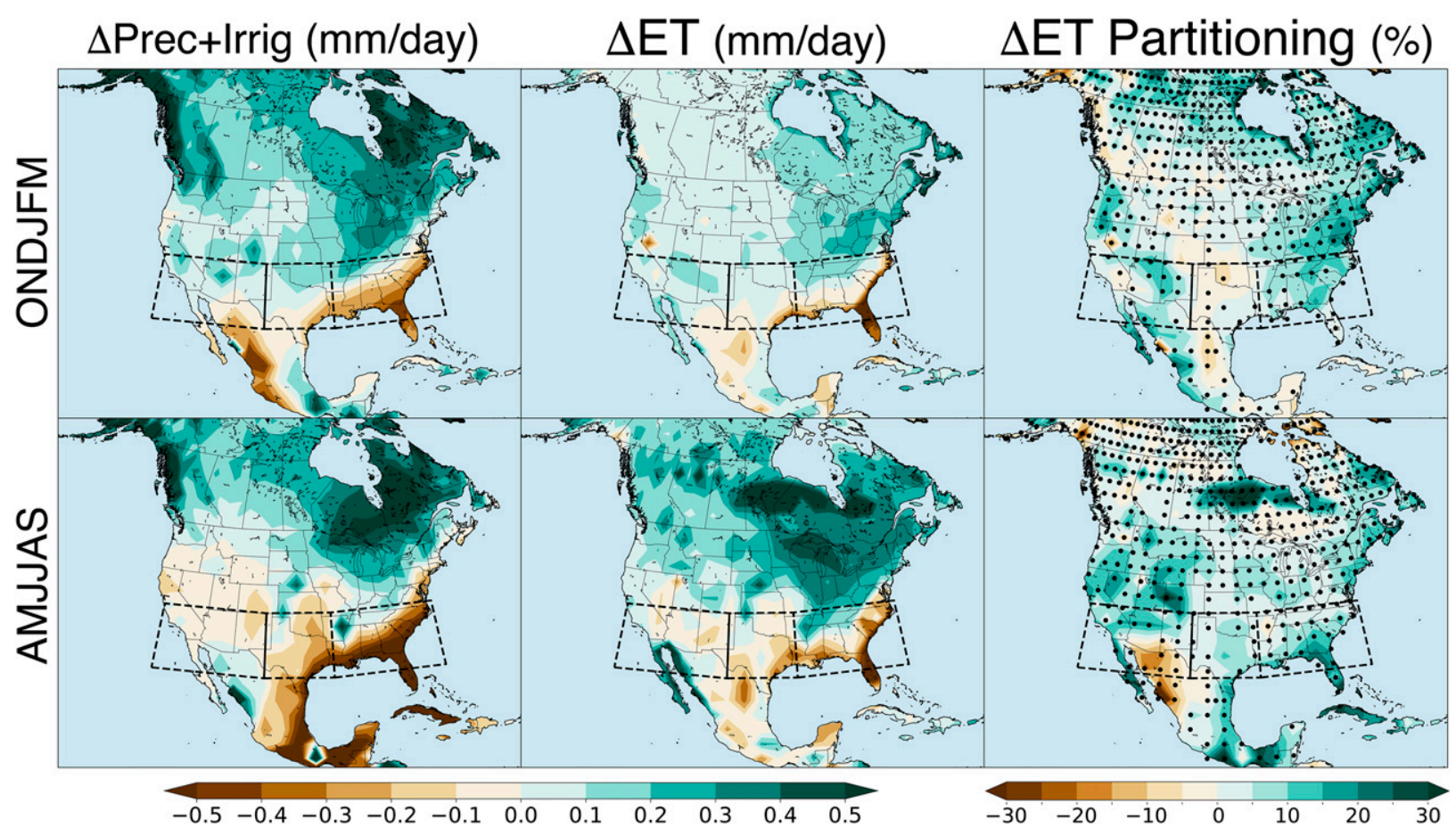

FIG. 14. Ensemble-average (top) cold season (ONDJFM) and (bottom) warm season (AMJJAS) changes in (left) surface water inputs (precipitation plus irrigation, $\left.\mathrm{mm} \mathrm{day}^{-1}\right)$, (center) total evapotranspiration $\left(\mathrm{mm} \mathrm{day}^{-1}\right)$, and (right) evaporative partitioning (defined as total evapotranspiration divided by total surface water inputs, percentage-point change) between the Fut-DRGHT and Hist-DRGHT periods. For the latter, blue-green anomalies indicate areas where an increased fraction of surface water inputs are being lost to the atmosphere through evapotranspiration. Areas with significant differences between the two drought periods (based on a two-sided Kolmogorov-Smirnov test, $p \leq 0.05$ ) are indicated by the black stippling.

Additionally, the important role of the land surface and vegetation processes in drought projections is being increasingly recognized (Cook et al. 2018), processes that often vary considerably in their treatment and sophistication across models (e.g., Trugman et al. 2018). For example, while irrigation has the potential to ameliorate modern and future drought impacts on crops, there are large uncertainties surrounding both the expected changes in irrigation requirements with warming and the actual capacity to supply the water needed to meet any increases in water demand. For our simulations, we chose a moderate irrigation scenario that assumes modern irrigation rates will be maintained in the future. More broadly, vegetation (cultivated and natural) is likely to respond to climate change and increasing atmospheric carbon dioxide concentrations in complex ways that may either ameliorate or amplify drought impacts at the surface. In response to increased atmospheric carbon dioxide concentrations, plants typically close their stomata, increasing water use efficiency (ratio of carbon gains to water losses by the plant) and countering warminginduced increases in evaporative demand, mitigating surface drying (e.g., Swann et al. 2016). Alternatively, plants may use this excess carbon to invest in biomass and growth. If this carbon is allocated to leaves, this could increase the effective area available for evapotranspiration, increasing total water losses even as water use efficiency increases (e.g., Mankin et al. 2017, 2018). Empirical evidence for which process is likely to dominate in the future is mixed (Cheng et al. 2017; De Kauwe et al. 2013; Frank et al. 2015; Keenan et al. 2013; Trancoso et al. 2017; Ukkola et al. 2016), and their relative importance appears to depend on the model, region, and even drought metric considered (Berg et al. 2017; Mankin et al. 2017, 2018; Milly and Dunne 2016; Swann et al. 2016). In GISS ModelE, photosynthesis and stomatal conductance both respond directly to increased atmospheric carbon dioxide concentrations, but leaf area and phenology are fixed in time. Plant physiological responses are therefore biased toward ameliorating evaporative losses. The impacts of increased evaporative demand on surface evapotranspiration in ModelE, and the associated drying, are therefore likely conservative, compared to models with dynamic phenology and vegetation.

Reducing or minimizing the impact of climate change on moisture deficits and water resources during droughts can potentially be addressed through both adaptation and climate change mitigation. As with most other 
climate-model-based analyses (Seager et al. 2013; Ting et al. 2018), the GISS-SST ensemble suggests that total precipitation will increase across much of the United States during the cold season. Even as a greater proportion falls as rain, there are potential opportunities to adapt by using the additional cold season precipitation water to compensate for enhanced deficits during the warm season. Indeed, such a thing has been suggested in a recent analysis of climate change projections for California, arguing that the most reliable models show substantial increases in cold season precipitation that could be used to address increased drought during the summer (Allen and Anderson 2018). Feasibility of such adaptation measures, however, depends on accuracy of the precipitation response in the models and the available infrastructure (e.g., reservoir storage capacity) to store the cold season surplus. Given the sensitivity of drought directly to temperature in climate change projections (e.g., through impacts on snow, evapotranspiration, etc.) there may also be substantial value in climate mitigation (i.e., reducing anthropogenic greenhouse gas emissions and the attendant warming). For example, Ault et al. (2016) demonstrated, for the Southwest United States, that future drought risk is significantly ameliorated under moderate versus high warming scenarios, a consequence of the strong response of drought to temperature and in spite of large uncertainties in precipitation. It is unlikely, however, that even the most aggressive mitigation options will be sufficient to completely address increases in drought risk with climate change in the future (King et al. 2017; Lehner et al. 2017), especially in light of the already detectable influence of climate change on recent droughts in the United States. Such conclusions highlight the likely necessity of implementing some adaptation measures, regardless of any future emissions trajectory.

Acknowledgments. B. I. Cook, R. Seager, A. P. Williams, and M. J. Puma were all supported for this work by the NASA Modeling, Analysis, and Prediction program (NASA 80NSSC17K0265). A. P. Williams was also supported by the NSF Paleo Perspectives on Climate Change (AGS 1703029). RS was also supported by NSF Award AGS01243204. Resources supporting this work were provided by the NASA High-End Computing (HEC) Program through the NASA Center for Climate Simulation (NCCS) at Goddard Space Flight Center. Lamont Contribution Number 8333.

\section{REFERENCES}

Allen, C. D., and D. D. Breshears, 1998: Drought-induced shift of a forest-woodland ecotone: Rapid landscape response to climate variation. Proc. Natl. Acad. Sci. USA, 95, 14 839-14 842, https://doi.org/10.1073/pnas.95.25.14839.
Allen, R. J., and R. G. Anderson, 2018: 21st century California drought risk linked to model fidelity of the El Niño teleconnection. npj Climate Atmos. Sci., 1, 21, https://doi.org/10.1038/ s41612-018-0032-x.

Andreadis, K., E. Clark, A. Wood, A. Hamlet, and D. Lettenmaier, 2005: Twentieth-century drought in the conterminous United States. J. Hydrometeor., 6, 985-1001, https://doi.org/10.1175/ JHM450.1.

Ault, T. R., J. S. Mankin, B. I. Cook, and J. E. Smerdon, 2016: Relative impacts of mitigation, temperature, and precipitation on 21st-century megadrought risk in the American Southwest. Sci. Adv., 2, e1600873, https://doi.org/10.1126/sciadv.1600873.

Berg, A., J. Sheffield, and P. C. D. Milly, 2017: Divergent surface and total soil moisture projections under global warming. Geophys. Res. Lett., 44, 236-244, https://doi.org/10.1002/ 2016GL071921.

Berg, N., and A. Hall, 2017: Anthropogenic warming impacts on California snowpack during drought. Geophys. Res. Lett., 44, 2511-2518, https://doi.org/10.1002/2016GL072104.

Bishop, D. A., and Coauthors, 2019: Investigating the causes of increased twentieth-century fall precipitation over the southeastern United States. J. Climate, 32, 575-590, https://doi.org/ 10.1175/JCLI-D-18-0244.1.

Bonfils, C. J. W., B. D. Santer, T. J. Phillips, K. Marvel, L. R. Leung, C. Doutriaux, and A. Capotondi, 2015: Relative contributions of mean-state shifts and ENSO-driven variability to precipitation changes in a warming climate. J. Climate, 28, 999710 013, https://doi.org/10.1175/JCLI-D-15-0341.1.

Cheng, L., and Coauthors, 2017: Recent increases in terrestrial carbon uptake at little cost to the water cycle. Nat. Commun., 8, 110, https://doi.org/10.1038/s41467-017-00114-5.

Chepil, W. S., F. H. Siddoway, and D. V. Armbrust, 1963: Climatic index of wind erosion conditions in the Great Plains. Soil Sci. Soc. Amer. J., 27, 449-452, https://doi.org/10.2136/sssaj1963. 03615995002700040025x.

Cook, B. I., T. R. Ault, and J. E. Smerdon, 2015a: Unprecedented 21st century drought risk in the American Southwest and central plains. Sci. Adv., 1, e1400082, https://doi.org/10.1126/ sciadv.1400082.

— S. P. Shukla, M. J. Puma, and L. S. Nazarenko, 2015b: Irrigation as an historical climate forcing. Climate Dyn., 44, 17151730, https://doi.org/10.1007/s00382-014-2204-7.

_ J. S. Mankin, and K. J. Anchukaitis, 2018: Climate change and drought: From past to future. Curr. Climate Change Rep., 4, 164-179, https://doi.org/10.1007/s40641-018-0093-2.

Dai, A., 2013: Increasing drought under global warming in observations and models. Nat. Climate Change, 3, 52-58, https:// doi.org/10.1038/nclimate1633.

De Kauwe, M. G., and Coauthors, 2013: Forest water use and water use efficiency at elevated $\mathrm{CO}_{2}$ : A model-data intercomparison at two contrasting temperate forest FACE sites. Global Change Biol., 19, 1759-1779, https://doi.org/10.1111/ gcb.12164.

Delworth, T. L., F. Zeng, A. Rosati, G. A. Vecchi, and A. T. Wittenberg, 2015: A link between the hiatus in global warming and North American drought. J. Climate, 28, 3834-3845, https://doi.org/10.1175/JCLI-D-14-00616.1.

Diaz, H. F., and E. R. Wahl, 2015: Recent California water year precipitation deficits: A 440-year perspective. J. Climate, 28, 4637-4652, https://doi.org/10.1175/JCLI-D-14-00774.1.

Döll, P., 2002: Impact of climate change and variability on irrigation requirements: A global perspective. Climatic Change, 54, 269-293, https://doi.org/10.1023/A:1016124032231. 
Elliott, J., and Coauthors, 2014: Constraints and potentials of future irrigation water availability on agricultural production under climate change. Proc. Natl. Acad. Sci. USA, 111, 32393244, https://doi.org/10.1073/pnas.1222474110.

Eyring, V., S. Bony, G. A. Meehl, C. Senior, B. Stevens, R. J. Stouffer, and K. E. Taylor, 2016: Overview of the Coupled Model Intercomparison Project Phase 6 (CMIP6) experimental design and organisation. Geosci. Model Dev., 9, 19371958, https://doi.org/10.5194/gmd-9-1937-2016.

Fasullo, J. T., B. L. Otto-Bliesner, and S. Stevenson, 2018: ENSO's changing influence on temperature, precipitation, and wildfire in a warming climate. Geophys. Res. Lett., 45, 9216-9225, https://doi.org/10.1029/2018GL079022.

Faurès, J.-M., J. Hoogeveen, and J. Bruinsma, 2002: The FAO irrigated area forecast for 2030. Food and Agriculture Organization of the United Nations, 14 pp., http://www.fao.org/3/ I9278EN/i9278en.pdf.

Frank, D. C., and Coauthors, 2015: Water-use efficiency and transpiration across European forests during the Anthropocene. Nat. Climate Change, 5, 579-583, https://doi.org/ 10.1038/nclimate2614.

Fuentes-Franco, R., F. Giorgi, E. Coppola, and F. Kucharski, 2016: The role of ENSO and PDO in variability of winter precipitation over North America from twenty first century CMIP5 projections. Climate Dyn., 46, 3259-3277, https:// doi.org/10.1007/s00382-015-2767-y.

Fye, F. K., D. W. Stahle, and E. R. Cook, 2003: Paleoclimatic analogs to twentieth-century moisture regimes across the United States. Bull. Amer. Meteor. Soc., 84, 901-909, https://doi.org/ 10.1175/BAMS-84-7-901.

Heim, R. R., 1988: About that drought.... Weatherwise, 41, 266271, https://doi.org/10.1080/00431672.1988.9925276.

_ 2017: A Comparison of the early twenty-first century drought in the United States to the 1930s and 1950s drought episodes. Bull. Amer. Meteor. Soc., 98, 2579-2592, https://doi.org/ 10.1175/BAMS-D-16-0080.1.

Herbel, C. H., F. N. Ares, and R. A. Wright, 1972: Drought effects on a semidesert grassland range. Ecology, 53, 1084-1093, https://doi.org/10.2307/1935420.

Herweijer, C., R. Seager, E. R. Cook, and J. Emile-Geay, 2007: North American droughts of the last millennium from a gridded network of tree-ring data. J. Climate, 20, 1353-1376, https://doi.org/10.1175/JCLI4042.1.

Hoerling, M., X. W. Quan, and J. Eischeid, 2009: Distinct causes for two principal US droughts of the 20th century. Geophys. Res. Lett., 36, L19708, https://doi.org/10.1029/2009GL039860.

Hughes, P., 1976: The worst droughts of the 20th century. American Weather Stories, Government Printing Office.

Kay, J. E., and Coauthors, 2015: The Community Earth System Model (CESM) Large Ensemble Project: A community resource for studying climate change in the presence of internal climate variability. Bull. Amer. Meteor. Soc., 96, 1333-1349, https://doi.org/10.1175/BAMS-D-13-00255.1.

Keenan, T. F., D. Y. Hollinger, G. Bohrer, D. Dragoni, J. W. Munger, H. P. Schmid, and A. D. Richardson, 2013: Increase in forest water-use efficiency as atmospheric carbon dioxide concentrations rise. Nature, 499, 324-327, https://doi.org/10.1038/nature12291.

King, A. D., D. J. Karoly, and B. J. Henley, 2017: Australian climate extremes at $1.5^{\circ} \mathrm{C}$ and $2^{\circ} \mathrm{C}$ of global warming. Nat. Climate Change, 7, 412-416, https://doi.org/10.1038/nclimate3296.

Knutti, R., and J. Sedlacek, 2013: Robustness and uncertainties in the new CMIP5 climate model projections. Nat. Climate Change, 3, 369-373, https://doi.org/10.1038/nclimate1716.
Lehner, F., S. Coats, T. F. Stocker, A. G. Pendergrass, B. M. Sanderson, C. C. Raible, and J. E. Smerdon, 2017: Projected drought risk in $1.5^{\circ} \mathrm{C}$ and $2^{\circ} \mathrm{C}$ warmer climates. Geophys. Res. Lett., 44, 7419-7428, https://doi.org/10.1002/2017GL074117. , C. Deser, I. R. Simpson, and L. Terray, 2018: Attributing the U.S. Southwest's recent shift into drier conditions. Geophys. Res. Lett., 45, 6251-6261, https://doi.org/10.1029/2018GL078312.

Lowry, R. L., 1959: A study of droughts in Texas. Texas Board of Water Engineers Bull. 5914, 81 pp., http://www.twdb.texas.gov/ publications/reports/bulletins/doc/B5914/B5914.pdf.

Mankin, J. S., J. E. Smerdon, B. I. Cook, A. P. Williams, and R. Seager, 2017: The curious case of projected twenty-firstcentury drying but greening in the American West. J. Climate, 30, 8689-8710, https://doi.org/10.1175/JCLI-D-17-0213.1.

, R. Seager, J. E. Smerdon, B. I. Cook, A. P. Williams, and R. Horton, 2018: Blue water tradeoffs with vegetation in a $\mathrm{CO}_{2}$-enriched climate. Geophys. Res. Lett., 45, 3115-3125, https://doi.org/10.1002/2018GL077051.

McCabe, G. J., M. A. Palecki, and J. L. Betancourt, 2004: Pacific and Atlantic Ocean influences on multidecadal drought frequency in the United States. Proc. Natl. Acad. Sci. USA, 101, 4136-4141, https://doi.org/10.1073/pnas.0306738101.

McGregor, K. M., 2015: Comparison of the recent drought in Texas to the drought of record using reanalysis modeling. Pap. Appl. Geogr., 1, 34-42, https://doi.org/10.1080/23754931.2015.1009295.

Meehl, G. A., C. Tebaldi, H. Teng, and T. C. Peterson, 2007: Current and future U.S. weather extremes and El Niño. Geophys. Res. Lett., 34, L20704, https://doi.org/10.1029/2007GL031027.

Milly, P. C. D., and K. A. Dunne, 2016: Potential evapotranspiration and continental drying. Nat. Climate Change, 6, 946-949, https://doi.org/10.1038/nclimate3046.

Moore, J. G., 2005: A half century of water resource planning and policy, 1950-2000. Water for Texas, J. Norwine, J. R. Giardino, and S. Krishnamurthy, Eds., Texas A\&M University Press, 5-16.

Mote, P. W., and Coauthors, 2016: Perspectives on the causes of exceptionally low 2015 snowpack in the western United States. Geophys. Res. Lett., 43, 10 980-10 988, https://doi.org/10.1002/ 2016GL069965.

— S. Li, D. P. Lettenmaier, M. Xiao, and R. Engel, 2018: Dramatic declines in snowpack in the western US. npj Climate Atmos. Sci., 1, 2, https://doi.org/10.1038/s41612-018-0012-1.

Nace, R. L., and E. J. Pluhowski, 1965: Drought of the 1950's with special reference to the midcontinent. Geological Survey Water-Supply Paper 1804, U.S. Government Printing Office, 93 pp., https://pubs.usgs.gov/wsp/1804/report.pdf.

Neilson, R. P., 1986: High-resolution climatic analysis and Southwest biogeography. Science, 232, 27-34, https://doi.org/10.1126/ science.232.4746.27.

Nielsen-Gammon, J., 2011: The 2011 Texas drought: A briefing packet for the Texas legislature. Office of the State Climatologist, College of Geosciences, Texas A\&M University Tech. Rep., 43 pp., https://senate.texas.gov/cmtes/82/c510/ 0110BI-JohnNielsen-Gammon.pdf.

Nigam, S., B. Guan, and A. Ruiz-Barradas, 2011: Key role of the Atlantic Multidecadal Oscillation in 20th century drought and wet periods over the Great Plains. Geophys. Res. Lett., 38, L16713, https://doi.org/10.1029/2011GL048650.

Oleson, K. W., 2013: Technical description of version 4.5 of the Community Land Model (CLM). NCAR Tech. Note NCAR/TN-503+STR, 420 pp., https://doi.org/10.5065/ D6RR1W7M.

Palmer, W. C., and L. H. Seamon, 1957: Drought in 1956. Weatherwise, 10, 22-25, https://doi.org/10.1080/00431672.1957.9926941. 
Power, S. B., and F. P. D. Delage, 2018: El Niño-Southern Oscillation and associated climatic conditions around the world during the latter half of the twenty-first century. J. Climate, $\mathbf{3 1}$, 6189-6207, https://doi.org/10.1175/JCLI-D-18-0138.1.

Puma, M. J., and B. I. Cook, 2010: Effects of irrigation on global climate during the 20th century. J. Geophys. Res., 115, D16120, https://doi.org/10.1029/2010JD014122.

Quiring, S. M., and G. B. Goodrich, 2008: Nature and causes of the 2002 to 2004 drought in the southwestern United States compared with the historic 1953 to 1957 drought. Climate Res., 36, 41-52, https://doi.org/10.3354/cr00735.

Rayner, N. A., D. E. Parker, E. B. Horton, C. K. Folland, L. V. Alexander, D. P. Rowell, E. C. Kent, and A. Kaplan, 2003: Global analyses of sea surface temperature, sea ice, and night marine air temperature since the late nineteenth century. J. Geophys. Res., 108, 4407, https://doi.org/10.1029/ 2002JD002670.

Scheff, J., and D. M. W. Frierson, 2014: Scaling potential evapotranspiration with greenhouse warming. J. Climate, 27, 15391558, https://doi.org/10.1175/JCLI-D-13-00233.1.

Schmidt, G. A., and Coauthors, 2014: Configuration and assessment of the GISS ModelE2 contributions to the CMIP5 archive. J. Adv. Model. Earth Syst., 6, 141-184, https://doi.org/ 10.1002/2013MS000265.

Schneider, U., A. Becker, P. Finger, A. Meyer-Christoffer, M. Ziese, and B. Rudolf, 2014: GPCC's new land surface precipitation climatology based on quality-controlled in situ data and its role in quantifying the global water cycle. Theor. Appl. Climatol., 115, 15-40, https://doi.org/10.1007/s00704-013-0860-x.

$\longrightarrow,-,-, \ldots$, and,- 2018 : GPCC full data monthly product version 2018 at $0.25^{\circ}$ : Monthly land-surface precipitation from rain-gauges built on GTS-based and historical data. GPCC, accessed 2018, https://doi.org/10.5676/DWD_GPCC/FD_M_ V2018 025.

Schubert, S. D., and Coauthors, 2009: A U.S. CLIVAR project to assess and compare the responses of global climate models to drought-related SST forcing patterns: Overview and results. J. Climate, 22, 5251-5272, https://doi.org/10.1175/2009JCLI3060.1.

_ - and Coauthors, 2016: Global meteorological drought: A synthesis of current understanding with a focus on SST drivers of precipitation deficits. J. Climate, 29, 3989-4019, https:// doi.org/10.1175/JCLI-D-15-0452.1.

Seager, R., 2007: The turn of the century North American drought: Global context, dynamics, and past analogs. J. Climate, 20, 5527-5552, https://doi.org/10.1175/2007JCLI1529.1.

_ , and M. Hoerling, 2014: Atmosphere and ocean origins of North American droughts. J. Climate, 27, 4581-4606, https:// doi.org/10.1175/JCLI-D-13-00329.1.

—, Y. Kushnir, C. Herweijer, N. Naik, and J. Velez, 2005: Modeling of tropical forcing of persistent droughts and pluvials over western North America: 1856-2000. J. Climate, 18, 4065-4088, https://doi.org/10.1175/JCLI3522.1.

— , N. Naik, and L. Vogel, 2012: Does global warming cause intensified interannual hydroclimate variability? J. Climate, 25, 3355-3372, https://doi.org/10.1175/JCLI-D-11-00363.1.

—- M. Ting, C. Li, N. Naik, B. Cook, J. Nakamura, and H. Liu, 2013: Projections of declining surface-water availability for the southwestern United States. Nat. Climate Change, 3, 482-486, https://doi.org/10.1038/nclimate1787.

, and Coauthors, 2014: Dynamical and thermodynamical causes of large-scale changes in the hydrological cycle over North America in response to global warming. J. Climate, 27, 7921-7948, https://doi.org/10.1175/JCLI-D-14-00153.1.
- M. Hoerling, S. Schubert, H. Wang, B. Lyon, A. Kumar, J. Nakamura, and N. Henderson, 2015: Causes of the 2011 to 2014 California drought. J. Climate, 28, 6997-7024, https:// doi.org/10.1175/jcli-d-14-00860.1.

Stahle, D. W., and M. K. Cleaveland, 1988: Texas drought history reconstructed and analyzed from 1698 to 1980. J. Climate, 1, 59-74, https://doi.org/10.1175/1520-0442(1988)001<0059: TDHRAA $>2.0 . \mathrm{CO} ; 2$

Stevenson, S. L., 2012: Significant changes to ENSO strength and impacts in the twenty-first century: Results from CMIP5. Geophys. Res. Lett., 39, L17703, https://doi.org/10.1029/ 2012GL052759.

Swann, A. L. S., F. M. Hoffman, C. D. Koven, and J. T. Randerson, 2016: Plant responses to increasing $\mathrm{CO}_{2}$ reduce estimates of climate impacts on drought severity. Proc. Natl. Acad. Sci. USA, 113, 10 019-10 024, https://doi.org/10.1073/pnas. 1604581113.

Swetnam, T. W., and J. L. Betancourt, 1998: Mesoscale disturbance and ecological response to decadal climatic variability in the American Southwest. J. Climate, 11, 3128-3147, https://doi.org/10.1175/1520-0442(1998)011<3128: MDAERT $>2.0 . \mathrm{CO} ; 2$.

Tedesco, J., 2015: 1950s drought plagued Texas for seven long years. San Antonio Express-News, https://www.expressnews.com/ 150years/major-stories/article/1950s-drought-plagued-Texasfor-seven-long-years-6500014.php.

Thomas, H. E., 1963: General summary of effects of the drought in the Southwest. Drought in the Southwest, 1942-1956, Geological Survey Paper 372, U.S. Government Printing Office, $33 \mathrm{pp}$.

Ting, M., R. Seager, C. Li, H. Liu, and N. Henderson, 2018: Mechanism of future spring drying in the southwestern United States in CMIP5 models. J. Climate, 31, 4265-4279, https:// doi.org/10.1175/JCLI-D-17-0574.1.

Trancoso, R., J. R. Larsen, T. R. McVicar, S. R. Phinn, and C. A. McAlpine, 2017: $\mathrm{CO}_{2}$-vegetation feedbacks and other climate changes implicated in reducing base flow. Geophys. Res. Lett., 44, 2310-2318, https://doi.org/10.1002/2017gl072759.

Trenberth, K. E., G. W. Branstator, D. Karoly, A. Kumar, N. C. Lau, and C. Ropelewski, 1998: Progress during TOGA in understanding and modeling global teleconnections associated with tropical sea surface temperatures. J. Geophys. Res., 103, 14 291-14 324, https://doi.org/10.1029/97JC01444.

Trugman, A. T., D. Medvigy, J. S. Mankin, and W. R. L. Anderegg, 2018: Soil moisture stress as a major driver of carbon cycle uncertainty. Geophys. Res. Lett., 45, 6495-6503, https://doi.org/ 10.1029/2018GL078131.

Turral, H., J. J. Burke, and J.-M. Faurès, 2011: Climate change, water and food security. Food and Agriculture Organization of the United Nations, Water Rep. 36, 200 pp., http:// www.fao.org/3/i2096e/i2096e.pdf.

Udall, B., and J. Overpeck, 2017: The twenty-first century Colorado River hot drought and implications for the future. Water Resour. Res., 53, 2404-2418, https://doi.org/10.1002/ 2016WR019638.

Ukkola, A. M., I. C. Prentice, T. F. Keenan, A. I. J. M. van Dijk, N. R. Viney, R. B. Myneni, and J. Bi, 2016: Reduced streamflow in water-stressed climates consistent with $\mathrm{CO}_{2}$ effects on vegetation. Nat. Climate Change, 6, 75-78, https://doi.org/ 10.1038/nclimate2831.

van Vuuren, D., and Coauthors, 2011: The representative concentration pathways: An overview. Climatic Change, 109, 5-31, https://doi.org/10.1007/s10584-011-0148-z. 
Wada, Y., and Coauthors, 2013: Multi-model projections and uncertainties of irrigation water demand under climate change. Geophys. Res. Lett., 40, 4626-4632, https://doi.org/10.1002/ grl.50686.

Weiss, J. L., J. L. Betancourt, and J. T. Overpeck, 2012: Climatic limits on foliar growth during major droughts in the southwestern USA. J. Geophys. Res., 117, G03031, https://doi.org/ 10.1029/2012JG001993.

Williams, A. P., R. Seager, J. T. Abatzoglou, B. I. Cook, J. E. Smerdon, and E. R. Cook, 2015: Contribution of anthropogenic warming to the 2012-2014 California drought. Geophys. Res. Lett., 42, 6819-6828, https://doi.org/10.1002/ 2015 GL064924.

, B. I. Cook, J. E. Smerdon, D. A. Bishop, R. Seager, and J. S. Mankin, 2017: The 2016 southeastern U.S. drought: An extreme departure from centennial wetting and cooling. J. Geophys. Res., 122, $10888-10905$, https://doi.org/10.1002/ $2017 \mathrm{jd} 027523$.

Winters, K. E., 2013: A historical perspective on precipitation, drought severity, and streamflow in Texas during 1951-56 and 2011. Scientific Investigations Rep. 2013-5113, U.S. Department of the Interior, U.S. Geological Survey, 34 pp., https://pubs. usgs.gov/sir/2013/5113/pdf/sir20135113.pdf.

Wisser, D., B. M. Fekete, C. J. Vorosmarty, and A. Schumann, 2010: Reconstructing 20th century global hydrography: A contribution to the Global Terrestrial Network-Hydrology (GTN-H). Hydrol. Earth Syst. Sci., 14, 1-24, https://doi.org/ 10.5194/hess-14-1-2010.

Woodhouse, C. A., and J. T. Overpeck, 1998: 2000 years of drought variability in the central United States. Bull. Amer. Meteor. Soc., 79, 2693-2714, https://doi.org/10.1175/15200477(1998)079<2693:YODVIT>2.0.CO;2.

— G. T. Pederson, K. Morino, S. A. McAfee, and G. J. McCabe, 2016: Increasing influence of air temperature on upper Colorado River streamflow. Geophys. Res. Lett., 43, 2174-2181, https://doi.org/10.1002/2015GL067613.

Xiao, M., B. Udall, and D. P. Lettenmaier, 2018: On the causes of declining Colorado River streamflows. Water Resour. Res., 54, 6739-6756, https://doi.org/10.1029/2018WR023153.

Yeh, S.-W., and Coauthors, 2018: ENSO atmospheric teleconnections and their response to greenhouse gas forcing. Rev. Geophys., 56, 185-206, https://doi.org/10.1002/2017RG000568. 